\title{
Synergetic monitoring of Saharan dust plumes and potential impact on surface: a case study of dust transport from Canary Islands to Iberian Peninsula
}

\author{
C. Córdoba-Jabonero ${ }^{1}$, M. Sorribas ${ }^{1}$, J. L.Guerrero-Rascado ${ }^{2, *}$, J. A. Adame ${ }^{1}$, Y. Hernández ${ }^{3}$, H. Lyamani ${ }^{2}$, \\ V. Cachorro ${ }^{4}$, M. Gil ${ }^{1}$, L. Alados-Arboledas ${ }^{2}$, E. Cuevas ${ }^{3}$, and B. de la Morena ${ }^{1}$ \\ ${ }^{1}$ Instituto Nacional de Técnica Aeroespacial (INTA), Atmospheric Research and Instrumentation Branch, Torrejón de Ardoz, \\ Madrid, Spain \\ ${ }^{2}$ Universidad de Granada (UGR), Andalusian Environmental Centre (CEAMA), Group of Atmospheric Physics, \\ Granada, Spain \\ ${ }^{3}$ Agencia Estatal de Meteorología (AEMET), Atmospheric Research Centre of Izaña, Sta. Cruz de Tenerife, Spain \\ ${ }^{4}$ Universidad de Valladolid (UVA), Group of Atmospheric Optics, Valladolid, Spain \\ *now at: Évora Geophysics Centre (CGE), University of Évora, Évora, Portugal
}

Received: 14 July 2010 - Published in Atmos. Chem. Phys. Discuss.: 9 November 2010

Revised: 10 March 2011 - Accepted: 18 March 2011 - Published: 1 April 2011

\begin{abstract}
The synergetic use of meteorological information, remote sensing both ground-based active (lidar) and passive (sun-photometry) techniques together with backtrajectory analysis and in-situ measurements is devoted to the characterization of dust intrusions. A case study of air masses advected from the Saharan region to the Canary Islands and the Iberian Peninsula, located relatively close and far away from the dust sources, respectively, was considered for this purpose. The observations were performed over three Spanish geographically strategic stations within the dust-influenced area along a common dust plume pathway monitored from 11 to 19 of March 2008. A 4-day long dust event (13-16 March) over the Santa Cruz de Tenerife Observatory (SCO), and a linked short 1-day dust episode (14 March) in the Southern Iberian Peninsula over the Atmospheric Sounding Station "El Arenosillo" (ARN) and the Granada station (GRA) were detected. Meteorological conditions favoured the dust plume transport over the area under study. Backtrajectory analysis clearly revealed the Saharan region as the source of the dust intrusion. Under the Saharan air masses influence, AERONET Aerosol Optical Depth at $500 \mathrm{~nm}\left(\mathrm{AOD}^{500}\right)$ ranged from 0.3 to 0.6 and Ångström Exponent at $440 / 675 \mathrm{~nm}$ wavelength pair $\left(\mathrm{AE}^{440 / 675}\right)$ was lower than 0.5 , indicating a high loading and predominance
\end{abstract}

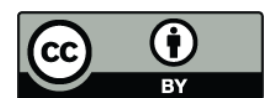

Correspondence to: C. Córdoba-Jabonero (cordobajc@inta.es) of coarse particles during those dusty events. Lidar observations characterized their vertical layering structure, identifying different aerosol contributions depending on altitude. In particular, the 3-km height dust layer transported from the Saharan region and observed over SCO site was later on detected at ARN and GRA stations. No significant differences were found in the lidar (extinction-to-backscatter) ratio (LR) estimation for that dust plume over all stations when a suitable aerosol scenario for lidar data retrieval is selected. Lidar-retrieved LR values of 60-70 sr were obtained during the main dust episodes. These similar LR values found in all the stations suggest that dust properties were kept nearly unchanged in the course of its medium-range transport. In addition, the potential impact on surface of that Saharan dust intrusion over the Iberian Peninsula was evaluated by means of ground-level in-situ measurements for particle deposition assessment together with backtrajectory analysis. However, no connection between those dust plumes and the particle sedimentation registered at ground level is found. Differences on particle deposition processes observed in both Southern Iberian Peninsula sites are due to the particular dust transport pattern occurred over each station. Discrepancies between columnar-integrated and ground-level in-situ measurements show a clear dependence on height of the dust particle size distribution. Then, further vertical size-resolved observations are needed for evaluation of the impact on surface of the Saharan dust arrival to the Iberian Peninsula.

Published by Copernicus Publications on behalf of the European Geosciences Union. 


\section{Introduction}

The important role that suspended matter plays in the radiative balance of the atmosphere is widely known, influencing both solar and thermal radiation. The evaluation of this aerosol-radiation interaction is essential for climate forcing assessment at both local and regional scales. However, large uncertainties exist at present caused, in particular, by an incomplete characterization of the optical, microphysical and chemical properties of the aerosols (IPCC, 2007).

Desert dust represents about $40 \%$ of aerosol loading yearly injected into the troposphere (Andreade, 1995). One half of this amount is attributed to the Saharan desert. Since 2001, different studies have reported more precise dust emission estimates ranging from 1000 to $2150 \mathrm{Tg} \mathrm{yr}^{-1}$ (see the review work of Zender et al., 2004, and references therein). Dust particles lifted by outbreaks in the Saharan region can travel very long distances (Hamonou et al., 1999; Ansmann et al., 2003). The arrival of dust plumes to the Mediterranean area and Europe is a common feature (Dulac et al., 1992; Moulin et al., 1998; Papayannis et al., 2008), and they have been reported from South of North America as well (Prospero, 1999; Prospero et al., 2002). In the course of that transport, physical and chemical transformations take place, affecting both the optical and microphysical properties of the particles. A long-range dust transport characterization of dust plumes crossing towards South Europe during the SAMUM 2006 campaign has been recently reported for transport modelling validation (Müller et al., 2009). In that work, EARLINET (European Aerosol Research LIdar NETwork, http://www.earlinet.org) measurements and AERONET (AErosol RObotic NETwork, http: //aeronet.gsfc.nasa.gov) data, among others, were used together with backtrajectory analysis, for that purpose. In general, this synergy between lidar and Cimel-photometry observations has also been widely used for mineral dust research (i.e., Ansmann et al., 2003; Müller et al., 2003, 2010a, b; Papayannis et al., 2005, 2008; Mona et al., 2006; Pérez et al., 2006) and other aerosol particles (i.e., Landulfo et al., 2003; Sicard et al., 2011). In particular, studies over the Mediterranean area by similar instrumentation are being carried out in order to assess the potential impact of the dust in the chemical processes occurring over that region (Balis et al., 2000; Papayannis et al., 2005; Mona et al., 2006; Dulac et al., 2009).

These studies reflect the importance of the synergetic use of both remote sensing from ground-based and satellite platforms and in-situ observations for the characterization of the vertical and horizontal distribution of dust. Height-resolved information of the dust properties is required for the understanding of the aerosol-ozone-UV interactions (i.e., Balis et al., 2002; Zerefos et al., 2002; Bonasoni et al., 2004), and even for both aerosol forecast modelling (i.e., Pérez et al., 2006) and satellite data evaluations (i.e., Mamouri et al., 2009; Pappalardo et al., 2010). On the other hand, the dust impact on surface is becoming relevant in socio-economical aspects and health issues (WMO, 2003).

A case study of medium-range dust transport from the Saharan region, as monitored crossing the Canary Islands and advected to the Iberian Peninsula, is shown in this study. Canary Islands present a singular location due to their close proximity to Saharan dust sources, acting as a first-detection site for relatively fresh-dust observations. The Iberian Peninsula represents the observational environment for potential transformation monitoring of those dust plumes, after being transported from the source regions. Several studies on this issue have previously been performed by using different aerosol active and passive techniques, modelling methods and air quality methodologies, including ground-based and satellite platforms (Müller et al., 2003; Lyamani et al., 2005; Pérez et al., 2006; Escudero et al., 2007; Toledano et al., 2007a, b; Cachorro et al., 2008; Guerrero-Rascado et al., 2008, 2009; Querol et al., 2008; Basart et al., 2009; Tesche et al., 2009). In this work we intend to extend that kind of dust characterization along the path to identify potential changes of the dust properties after being transported over the Atlantic Ocean, and its impact on surface deposition.

The aim of this work is focused on the monitoring of a dust plume coming from the Saharan region, regarding both vertical structure and physical/optical features and its potential surface deposition. Lidar, sun-photometry and surface insitu measurements are used for that purpose. Three Spanish strategic stations deployed along the same path of this dust plume are selected: the subtropical Santa Cruz de Tenerife Observatory (SCO-AEMET), around $1000 \mathrm{~km}$ from the Saharan dust sources, and two sites located in the South of the Iberian Peninsula: the Atmospheric Sounding Station "El Arenosillo" (ARN-INTA), and the Granada station (GRAUGR), placed at around $1350 \mathrm{~km}$ and $1600 \mathrm{~km}$, respectively, from the Canary Islands. A dust event sequentially passing through all three stations on March 2008 was monitored and analyzed. Synergetic use of AERONET columnar-integrated data for dust intrusion evidence and meteorological synoptic situation together with backtrajectory analysis for dust plume tracking completes this study.

A description of the measurements sites and methodology used in this work is detailed in Sects. 2 and 3, respectively. A meteorological overview for the monitored period is shown in Sect. 4. Section 5 presents results and discussion. The main conclusions are exposed in Sect. 6.

\section{Measurement sites}

Three Spanish stations, strategically located within the dustinfluenced area and with lidar, sun-photometry and surface in-situ measurement capabilities, have been chosen for this study. The relative position to the Saharan region of these three sites is shown in Fig. 1. 


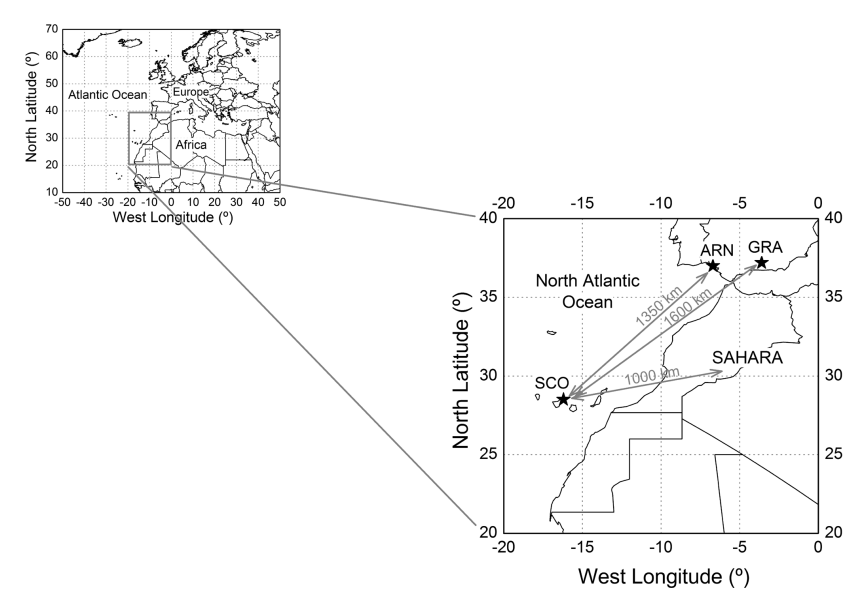

Fig. 1. Map showing the geographical situation of the three stations, Santa Cruz de Tenerife (SCO), "El Arenosillo" (ARN) and Granada (GRA) respect to Saharan dust sources.

\subsection{Santa Cruz de Tenerife Observatory (SCO-AEMET)}

The Santa Cruz de Tenerife Observatory (SCO) is a subtropical station $\left(28.5^{\circ} \mathrm{N} 16.2^{\circ} \mathrm{W}, 52 \mathrm{~m}\right.$ a.s.l. $)$, located at a coastal urban background of Tenerife (Canary Islands). SCO station is managed by the Atmospheric Research Centre of Izaña (CIAI) of the Spanish Agency of Meteorology (AEMET). This station is both a NASA/AERONET and NASA/MPLNET (MicroPulse Lidar NETwork, http: $/ /$ mplnet.gsfc.nasa.gov) site, and it is part of the recently formed Spanish and Portuguese Aerosol Lidar NETwork (SPALINET, http://www.lidar.es/spalinet/). Atmospheric research is focused on both trace gases and particles measurements by using in-situ techniques and meteorological monitoring. Remote sensing techniques (lidar, sun-photometry) are also used to complement the aerosol measurement program at SCO site. This station has an excellent location and qualities for different atmospheric phenomena studies.

Dust research has been performed over SCO station by using both AERONET columnar-integrated data and different surface in-situ measurements for air quality assessment. Results indicate that the mineral dust dominates the aerosol regime as a consequence of frequent Saharan dust outbreaks (Basart et al., 2009). $\mathrm{PM}_{10} / \mathrm{PM}_{2.5}$ (Particulate Monitor for aerosols less than 10 and $2.5 \mu \mathrm{m}$ size, respectively) concentrations found during African dust outbreaks were higher in SCO than in any other Spanish stations due to its close proximity to African desert source regions (Querol et al., 2008).

\subsection{Atmospheric Sounding Station "El Arenosillo" (ARN-INTA)}

The Atmospheric Sounding Station "El Arenosillo" (ARN) belongs to the National Institute for Aerospace Technology (INTA) and it is at the Southwest of the Iberian Peninsula
(37. $1^{\circ} \mathrm{N} 6.7^{\circ} \mathrm{W}, 40 \mathrm{~m}$ a.s.1.). ARN is an NASA/AERONET site, and devoted to atmospheric research by in-situ and remote sensing techniques. "El Arenosillo" observatory is located in a rural protected environment, near Doñana National Park, and less than $1 \mathrm{~km}$ from the Atlantic coastline. The station has an exceptional situation for first dust detection once crossing over the Southwestern Iberian Peninsula.

Dust research has been accomplished by both AERONET columnar-integrated and surface in-situ measurements analysis. Previously reported AERONET data for desert dust events over this site indicate high turbidity and a predominance of coarse particles (Toledano et al., 2007a, b). In addition, desert dust air masses presented a relevant annual frequency of $18 \%$ with a mean duration period of 4 days, and they were more frequent in February/March and summer months (Prats et al., 2008; Toledano et al., 2009). The strongest North African desert dust intrusion over the Iberian Peninsula was also analyzed over this site (Cachorro et al., 2008). Surface in-situ measurements during 2004 summertime show relevant absorption coefficients (Mogo et al., 2005) and main $\mathrm{PM}_{10}$ sources were regional, crustal, industrial and marine (González-Castanedo et al., 2008). Analysis of the sub-micrometer particle number size distribution under different aerosol-type occurrence shows a predominance of accumulation mode particles for desert dust aerosol with a modal diameter around $0.1 \mu \mathrm{m}$ (Sorribas, 2008). ARN is a representative rural background site in the Iberian Peninsula, where desert dust intrusions are relatively frequent.

\subsection{Granada station (GRA-UGR)}

Granada station (GRA) is a non-industrialized urban observatory placed in a natural basin at $680 \mathrm{~m}$ a.s.l. in the Southeast of the Iberian Peninsula $\left(37.2^{\circ} \mathrm{N} 3.6^{\circ} \mathrm{W}\right), 50 \mathrm{~km}$ away from the Mediterranean coast and surrounded by a high mountain range with altitudes above $3000 \mathrm{~m}$. It is managed by the Andalusian Environmental Centre (CEAMA) of the University of Granada (UGR). GRA site is both a NASA/AERONET and EARLINET station, and it is also part of SPALINET as SCO site. Aerosol instrumentation by active and passive remote sensing and in-situ measurements, allows monitoring and characterizing a wide array of atmospheric parameters.

Atmospheric aerosol properties have widely been studied over Granada by using both ground-based sun-photometer and lidar data (Alados-Arboledas et al., 2003, 2008; Lyamani et al., 2004, 2005, 2006a, b, 2008; Guerrero-Rascado et al., 2008). Recently Guerrero-Rascado et al. (2009) reported an extreme Saharan dust outbreak from different measurements (active/passive and ground-based/satellite), revealing the importance of multi-instrumental measurements to properly characterize the contribution of different aerosol types from different sources. Aerosol research by using surface in-situ measurements (i.e., Lyamani et al., 2008, 2010) indicates that the particle properties follow a clear diurnal pattern with two 
local maxima occurring in early morning and late evening, caused by local conditions.

\section{Methodology}

Height-resolved measurements of a dust intrusion are carried out by ground-based aerosol lidars over all three sites. Dust impact on the Iberian Peninsula surface has been evaluated by size-resolved and optical in-situ measurements. Sunphotometry data and air mass backtrajectory analysis are also included in this study.

\subsection{Ground-based lidars: height-resolved measurements}

A detailed description of the three aerosol lidars used in this work and their data processing is presented. Their main characteristics are shown in Table 1.

\subsubsection{SCO and ARN systems}

Two INTA Micropulse Lidars (MPL), MPL-3 (SES Inc., USA) and MPL-4 (Sigma Space Corp., USA) systems patented by NASA, were deployed at SCO and ARN, respectively, for dust monitoring over these sites. MPL-3 system is the standard micropulse lidar currently in operation within NASA/MPLNET. An improved version, the MPL-4 system, was temporarily installed at ARN in November 2007 to carry out complementary measurements on aerosol monitoring. MPL is a robust system with high-pulsed $(2500 \mathrm{~Hz})$ and low-energy (7-10 $\mu \mathrm{J}$, maximal) 'eye-safe' Nd:YLF laser at $523 \mathrm{~nm}$ (MPL-3) and $527 \mathrm{~nm}$ (MPL-4), operational in fulltime continuous mode ( $24 \mathrm{~h}$ a day/365 days a year). These features make available both the temporal and vertical evolution of the dust layering structure with a good resolution.

The MPL backscattered signal is registered at 1-min integrated time and with a vertical resolution of $75 \mathrm{~m}$, as for NASA/MPLNET requirements. MPL raw signal is corrected by several factors affecting the instrument, as described by Campbell et al. (2002), including the overlap correction. A detailed study on the uncertainties introduced in the raw signal correction from each of the instrumental effects for this kind of micropulse lidars can be found in Welton and Campbell (2002), being the overlap uncertainty the most dominant in the near-range. Finally, full-corrected profiles are hourly averaged in order to increase the signal-to-noise ratio (SNR).

In particular, a full overlap is reached at $5 \mathrm{~km}$ height for both MPLs. Corrections procedures reported in Campbell et al. (2002) have been performed in order to minimize uncertainties (Welton and Campbell, 2002). Above ground level (a.g.l.) from $500 \mathrm{~m}$ height up overlap uncertainties are in the range of $10-50 \%$, leading to errors of $10-40 \%$ in the data. Data below $500 \mathrm{~m}$ height a.g.l. are disregarded for the analysis due to too large errors by the intrinsic limitation of the system configuration.

\subsubsection{GRA system}

The Raman lidar model LR331D400 (Raymetrics S.A., Greece) is a robust system configured in a monostatic biaxial alignment, pointing vertically to the zenith. It is based on a pulsed Nd:YAG laser with fundamental emission at $1064 \mathrm{~nm}$, and additional emissions at 532 and $355 \mathrm{~nm}$ by using second and third harmonic generators. Output energies are 110, 65 and $60 \mathrm{~mJ}$ at 1064, 532 and $355 \mathrm{~nm}$, respectively, and pulses of 7 to $9 \mathrm{~ns}$ can be fired with a pulse repetition frequency (PRF) of 1, 2, 5 and $10 \mathrm{~Hz}$ (a PRF of $10 \mathrm{~Hz}$ has been used in this study). The receiving system consists of a Cassegrain telescope and a wavelength separation unit with dichroic mirrors, interferential filters and a polarization cube, that discriminates seven channels corresponding to elastic wavelengths $(1064,532$ parallel-polarized, 532 perpendicularpolarized, and $355 \mathrm{~nm}$ ), and to nitrogen and water vapour Raman-shifted wavelengths (387, 408, and $607 \mathrm{~nm}$ ). Raman signals are only used for night-time retrievals.

Lidar backscattered signals are registered at 1-min integrated time and a vertical resolution of $7.5 \mathrm{~m}$. Full overlap is reached at around $1900 \mathrm{~m}$ a.s.l. (GRA station is located at $680 \mathrm{~m}$ a.s.l.). An overlap correction is then applied on the basis of the simple technique proposed by Wandinger and Ansmann (2002), down to the height where the overlap function is equal to $0.6-0.7$. This correction allows extending the profile in most cases down to $1200 \mathrm{~m}$ a.s.l., i.e. down to $500 \mathrm{~m}$ above the GRA station (Navas-Guzmán et al., 2011).

\subsubsection{Lidar data processing for optical parameters retrieval}

A Klett-Fernald-Sasano iterative inversion algorithm (Fernald et al., 1972; Klett, 1981, 1985; Fernald, 1984; Sasano and Nakane, 1984; Sasano et al., 1985) is applied to retrieve the height-resolved aerosol backscatter coefficients (molecular backscatter coefficients are obtained from local radiosoundings, when available). AERONET Aerosol Optical Depth (AOD) is used to constraint the algorithm convergence by "tuning" the lidar ratio (LR, extinction-tobackscatter ratio) values. Once the AOD convergence is obtained (less than 10\%), a height-constant LR is estimated (errors of $15 \%$ are found from AOD convergence uncertainty). Thus, the "guessed" extinction coefficients can be retrieved, and a lidar-derived hourly-integrated AOD is calculated from day- and night-time measurements. As stated before, due to the large overlap uncertainties below $500 \mathrm{~m}$ height a.g.l., data in this range are disregarded for that approach and then a boundary layer (BL) homogeneously mixed is assumed instead.

In the frame of SPALINET, a complete study on lidar system and data retrieval intercomparison (Sicard et al., 2009) was carried out. Indeed, both SCO and GRA lidars were involved in that study. Full-corrected data (overlap correction included) and then retrieved backscatter coefficients profiles 
Table 1. Main characteristics of the three lidars used in this study.

\begin{tabular}{llll}
\hline Lidar system & MPL-3 & MPL-4 & GRA lidar \\
\hline Station & SCO & ARN & GRA \\
& $\left(28.5^{\circ} \mathrm{N} 16.2^{\circ} \mathrm{W}\right.$, & $\begin{array}{l}\left(37.0^{\circ} \mathrm{N} 6.7^{\circ} \mathrm{W},\right. \\
(52 \mathrm{~m} \text { a.s.l. })\end{array}$ & $\begin{array}{l}\left(37.2^{\circ} \mathrm{N} 3.6^{\circ} \mathrm{W},\right. \\
680 \mathrm{~m} \text { a.s.1. })\end{array}$ \\
\hline Routine operation & Yes & No, & Yes \\
& & temporal installation & \\
Networks & MPLNET & - & EARLINET \\
& SPALINET & & SPALINET \\
Wavelength $(\mathrm{nm})$ & 523 & 527 & 532 \\
& & & (used in this study) \\
Energy/pulse $(\mathrm{mJ})$ & 0.007 (max.) & 0.010 (max.) & 65 \\
Pulse repetition frequency $(\mathrm{Hz})$ & 2500 & 2500 & 10 \\
Eye-safe & Yes & Yes & No \\
Raman capability & No & No & Yes \\
\hline
\end{tabular}

were found to be inside the uncertainty values allowed as for the EARLINET quality control tolerances (Matthias et al., 2004) followed in that intercomparison, i.e., the mean and standard deviations between lidar systems stayed below the maximum allowed values fixed (20\% and 25\%, respectively, for backscatter at $532 \mathrm{~nm}$ ). ARN system was tested against the Koldewey Aerosol Raman Lidar (KARL), managed by the Alfred-Wegener Institute (AWI, Germany) and devoted to long-term Arctic aerosol observations. In particular, both lidars were vertically pointing under free-aerosol conditions for overlap approach in the near-range. Once overlap was estimated, full-corrected data and their uncertainties were obtained. Backscatter coefficients profiles were retrieved and compared to the KARL measurements in the near-range for polar tropospheric aerosols and in the far-range for PSC detection. Intercomparison results showed a good agreement on instrument performance and data retrieval between both datasets (Córdoba-Jabonero et al., 2008, 2009; R. Neuber and C. Córdoba-Jabonero, personal communication, 2008).

\subsection{Surface in-situ instrumentation: size-resolved measurements}

Both ARN and GRA sites have similar instrumentation to characterize surface in-situ aerosol particle properties. Particles in the micrometer-size range were monitored with an Aerodynamic Particle Size (APS) Spectrometer (TSI Mod. 3321). This instrument is a time-of-flight spectrometer measuring the velocity of particles in an accelerating air flow though a nozzle (Holm et al., 1997). Conversion of the aerodynamic into mobility diameter of the micrometer particle number distribution is performed by using the algorithm described by Sioutas et al. (1999) and assuming an effective particle density of $2.0 \mathrm{~g} \mathrm{~cm}^{-3}$ for spherical particles. This value was obtained at ARN site (Fernández-León et al., 2010) by comparison between the mass concentrations measured with a SMPS-APS system and a DLPI (Dekati Low Pressure Impactor). In GRA case, the estimated density was calculated from chemical composition averaging by using the GRA aerosol $\mathrm{PM}_{10}$-PM1 database (Titos-Vela et al., 2010). The density for each chemical constituent reported by Khlystov et al. (2004) was also assumed, but considering a density of $2.2 \mathrm{~g} \mathrm{~cm}^{-3}$ for marine and crustal components. Stokes corrections were also applied (Wang and Walter, 1987).

In addition, an integrating nephelometer (TSI Mod. 3563), backscatter shutter included, was used for scattering and backscattering particle properties measurements by splitting the scattered light into blue $(450 \mathrm{~nm})$, green $(550 \mathrm{~nm})$ and red (700 nm) wavelengths. Thus, an additional Ångström exponent $\left(\mathrm{AE}_{\mathrm{np}}\right) \mathrm{can}$ be inferred from these nephelometer measurements. Other parameter to be examined was the fraction of backscattered light at $550 \mathrm{~nm}$ (backscatter fraction, $\mathrm{BSC}^{550}$ ), defined as the ratio of the integral of the volume scattering function over the backward half solid angle divided by the same one over the full solid angle. Truncation and angular scattering corrections were applied (Anderson and Ogren, 1998).

Dry ambient sub-micrometer size distributions were monitored only in ARN site by using a Scanning Mobility Particle Sizer (SMPS) (Electrostatic Classifier TSI Mod. 3080 and a Condensation Particle Counter TSI Mod. 3022A). This particle spectrometer uses the relation between the particle mobility and the diameter to calculate the particle size (Knutson and Whitby, 1975). Data were obtained in the size range of $14.5-604 \mathrm{~nm}$ by using rates of 0.3 and $3.01 \mathrm{~min}^{-1}$ for aerosol and sheath flows, respectively. Volume size distribution for sub-micrometer aerosols was calculated by assuming spherical particles. Datasets were also corrected for losses caused by diffusion processes inside the instrument (Willeke and Baron, 1993). 


\subsection{AERONET data: columnar-integrated measurements}

All three stations are AERONET sites, routinely performing ground-based aerosol monitoring to assess optical and microphysical properties of the suspended particles. Columnar-integrated data are used for dust intrusion evidence. AERONET inversion products (Dubovik and King, 2000; Dubovik et al., 2002a, 2006) of level 1.5 (Cloud Screened) are used in this work. Main AERONET parameters used to evidence the dust signature are the Aerosol Optical Depth (AOD) and the Ångström Exponent (AE): high $\mathrm{AOD}$ and low (even close to zero) AE values indicate the presence of dust (predominance of coarse particles) representing dusty conditions over the observational site (Lyamani et al., 2005; Pérez et al., 2006; Toledano et al., 2007a, b; Cachorro et al., 2008; Guerrero-Rascado et al., 2009; Basart et al., 2009). Other retrievals like the single scattering albedo (SSA) and phase function at $180^{\circ}\left(\mathrm{P}_{180^{\circ}}\right)$ are taken into account to derive a columnar-integrated LR (LR ${ }^{\text {AERONET }}$ ) according to the expression (Welton et al., 2002):

$\mathrm{LR}^{\mathrm{AERONET}}=4 \pi / \mathrm{SSA} \times \mathrm{P}_{180^{\circ}}$

These $\mathrm{LR}^{\mathrm{AERONET}}$ values are considered for lidar ratio evaluation in comparison with those estimated by using lidar retrieval algorithms. Moreover, AERONET particle columnar-integrated size distribution inversions are also available for that dusty period at ARN and GRA sites, and then they are used for comparison with ground-level in-situ size-resolved concentration measurements.

Spectrally resolved AOD, AE and those other optical parameters (SSA and $\mathrm{P}_{180^{\circ}}$ ) are derived at visible wavelengths close to the lidar laser wavelength (523-532 nm), depending on the spectral availability for each station. AOD at $500 \mathrm{~nm}$ $\left(\mathrm{AOD}^{500}\right)$ is the one selected, when available; otherwise the Ångström formulation (Ångström, 1964) is used to derive it. The $\mathrm{AE}$ for the $440 / 675 \mathrm{~nm}$ wavelength pair $\left(\mathrm{AE}^{440 / 675}\right)$ is taken and mean SSA and $\mathrm{P}_{180^{\circ}}$ values between those at 440 and $675 \mathrm{~nm}$ are obtained for LR ${ }^{\text {AERONET }}$ calculations.

In the basis of the results obtained by Dubovik et al. (2002b), where high values of AOD were found to characterize turbid atmospheres as opposite to clean ones dominated by oceanic aerosols (i.e., oceanic background aerosol loading was found to be related to $\mathrm{AOD}<0.15$ ), this threshold AOD of 0.15 is adopted as a criterion to divide the aerosol loading into low and moderate/high contents.

In addition, a recent study on aerosol characterization from direct-sun AERONET observations in 39 stations (Basart et al., 2009) reports seasonal AOD and AE mean values of large aerosols fraction (corresponding to particles with $\mathrm{AOD}>0.15$ and $\mathrm{AE}<0.75$ ) for each station. In particular, AODs of 0.43 , 0.35 and 0.28 and AEs of $0.37,0.39$ and 0.43 were obtained in springtime (March-May) for SCO, ARN and GRA sites, respectively.
Therefore, the final criterion adopted for dust (predominance of coarse particles) evidence (Dubovik et al., 2002b; Basart et al., 2009) is based on: (1) $\mathrm{AOD}^{500}$ values, representing thus a low $\left(\mathrm{AOD}^{500}<0.15\right)$, moderate $\left(0.15<\mathrm{AOD}^{500}<0.35\right)$ and high $\left(\mathrm{AOD}^{500}>0.35\right)$ aerosol loading over the station; and (2) a threshold $\mathrm{AE}^{440 / 675}$ value $<0.5$ for dust identification. In this sense, two principal aerosol atmospheric scenarios have been selected: non-dusty conditions with low $\mathrm{AOD}^{500}(<0.15)$ and $\mathrm{AE}^{440 / 675}>0.5$, and dusty conditions corresponding to moderate and high $\mathrm{AOD}^{500}(>0.15)$ and $\mathrm{AE}^{440 / 675}<0.5$.

Moreover, AERONET columnar-integrated size distributions (VSD ${ }^{\text {AERONET }}$ ) are devoted to evaluate to some extent the dust impact on the surface in the Southern Iberian Peninsula. Unfortunately, there are scarce VSD ${ }^{\text {AERONET }}$ available during the dusty period in both ARN and GRA sites; however, they are compared with that calculated from the most coincident in time ground-level in-situ measurements. Other relevant parameters as the ratio of the fine-to-total mode of the VSD ${ }^{\mathrm{AERONET}}\left(\mathrm{V}_{\mathrm{F} / \mathrm{T}}^{\mathrm{AERONET}}\right)$ and the effective radius $\left(r_{\text {eff }}^{\text {AERONET }}\right)$ for the total, fine and coarse modes of those $\mathrm{VSD}^{\mathrm{AERONET}}$ are also examined for that purpose.

\subsection{Air masses backtrajectory analysis}

Backtrajectories are calculated to determine the origin and the pathway of the air masses affecting the three stations involved in this study. Backtrajectory analysis is performed by using the Hybrid Single Particle Lagrangian Integrated Trajectory (HYSPLIT) model Version 4 developed by the NOAA's Air Resources Laboratory (ARL) (Draxler and Hess, 1998; Draxler et al., 2009). GDAS (Global Data Analysis System) meteorological files with a spatial resolution of $1^{\circ} \times 1^{\circ}$ every $3 \mathrm{~h}$, generated and maintained by ARL, are used as data input. Kinematical three dimensional backtrajectories are calculated using the vertical wind component given by the meteorological model (Stohl, 1998).

In particular, the dust intrusions observed over each station can be thus potentially associated to Saharan sources by examining the HYSPLIT 5-day air mass backtrajectories for each one of the three stations (SCO, ARN and GRA). In order to understand the behaviour of the air masses circulating in the boundary layer (BL) and the free troposphere (FT), backtrajectories at three different altitudes a.g.l. have been calculated: $500 \mathrm{~m}$ (near the surface), $1500 \mathrm{~m}$ (representative of the BL top) and $3000 \mathrm{~m}$ (characteristic for FT heights).

\section{Meteorological overview}

The meteorological situation is examined to explain the synoptic conditions that originate those aerosol scenarios. Synoptic charts are provided by the NOAA/ESRL Physical Sciences Division from their website at http://www.esrl.noaa. gov/psd/ (Kalnay et al., 1996). Selected charts at three 

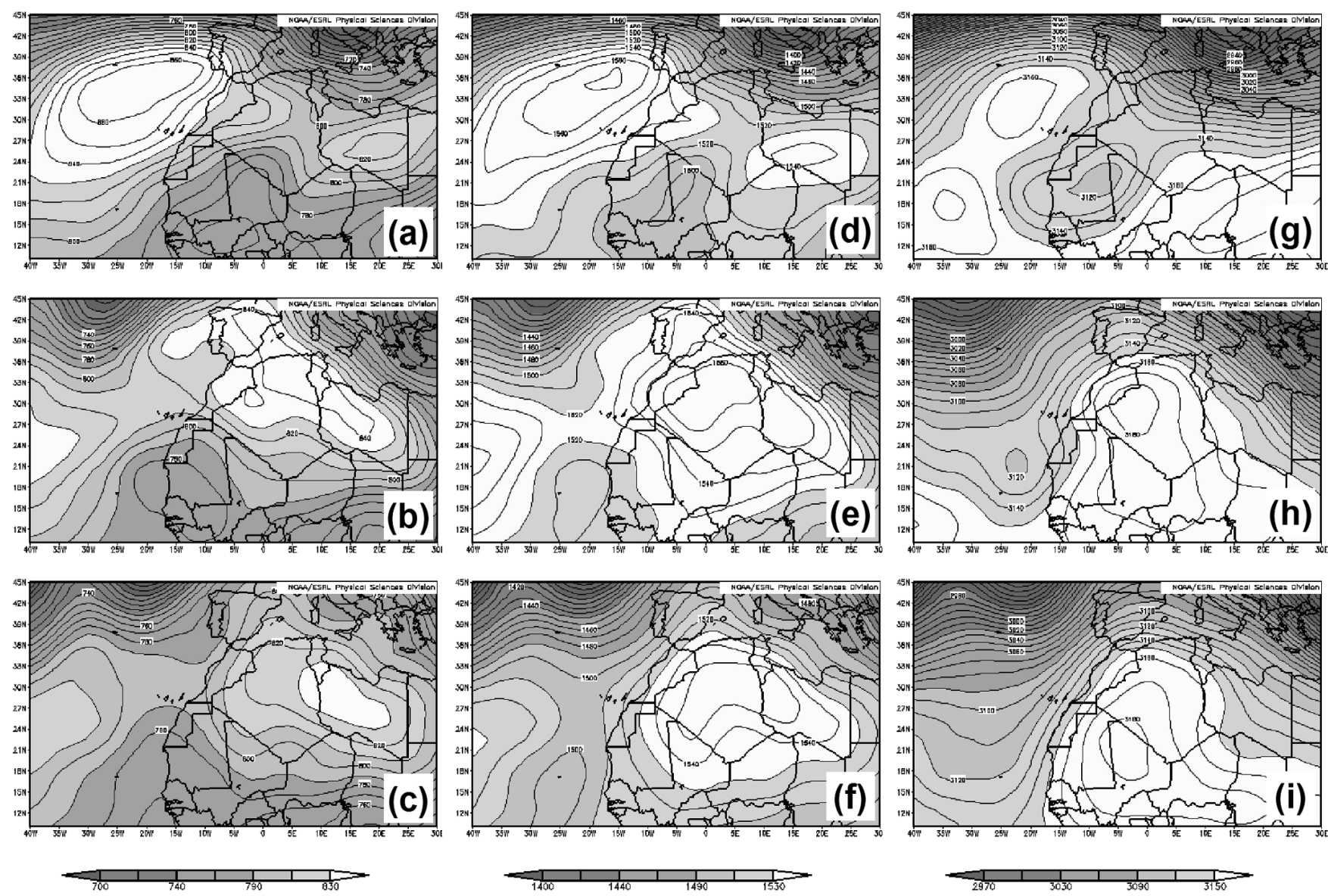

Fig. 2. Meteorological synoptic charts at three geopotential heights: $950 \mathrm{hPa}(800 \mathrm{~m}$ a.s.l., a-c), $850 \mathrm{hPa}(1500 \mathrm{~m}$ a.s.l., d-f) and $700 \mathrm{hPa}$ (around $3000 \mathrm{~m}$ a.s.l., g-i). Figure panels correspond to three different dates as representative of both non-dusty and dusty conditions depending on each station (from top to bottom panels): 11, 13 and 14 March 2008.

geopotential heights: $700 \mathrm{hPa}$ (around $3000 \mathrm{~m}$ a.s.1.), $850 \mathrm{hPa}$ (1500 $\mathrm{m}$ a.s.l.) and $925 \mathrm{hPa}(800 \mathrm{~m}$ a.s.l.), for three different dates as representative of both non-dusty and dusty conditions depending on each station are shown in Fig. 2.

Meteorological conditions on 11 March are characterized by an Atlantic high pressure system centered over the North Atlantic, between the Azores Islands and the Canary Islands, a low pressure system over Mauritania at $700 \mathrm{hPa}$ (around $3000 \mathrm{~m}$ a.s.1.), and an enhanced Azores High system shifted eastwards at $850 \mathrm{hPa}(1500 \mathrm{~m}$ a.s.l) and $925 \mathrm{hPa}$ ( $800 \mathrm{~m}$ a.s.l.). This situation favours the arrival of Atlantic air masses from Northwestern and Western directions to both ARN and GRA stations. Nevertheless, Atlantic air masses arrive at SCO station by different pathways, in this case from Northeastern direction. Little changes are observed in the synoptic situation next day (12 March). Air masses have the same origin but with a major influence from Western direction to ARN and GRA areas. In the case of SCO site, air masses arrive from Northeastern direction but with a pathway very close to the African coastline.
On 13 March a strong Atlantic high pressure system is well identified over Northern Africa at $700 \mathrm{hPa}$, extending over the Iberian Peninsula at $850 \mathrm{hPa}$ and $950 \mathrm{hPa}$. This synoptic situation favours a Southwestern flow over ARN and GRA sites, while SCO site is directly affected by air masses arriving directly from the African continent.

Synoptic meteorology on 14 March is determined by a high pressure system centred over Mali at $700 \mathrm{hPa}$ and over Algeria and Libya at $850 \mathrm{hPa}$ and $925 \mathrm{hPa}$, respectively. This configuration causes the arrival of air masses from the African continent at the three altitude levels considered and over all three stations (see Fig. 2). However, the air masses arriving at SCO site have their origin at similar latitudes to the Canary Islands (over the Western Sahara) while the Saharan air masses reaching both ARN and GRA stations have their origin at higher latitudes of the African continent.

Next day (15 March) a change in the synoptic conditions is observed. The Western flow affecting both ARN and GRA sites is completely disconnected from air masses over the $\mathrm{Ca}$ nary Islands which are still originated over the Saharan region. Therefore, dust levels over SCO station would remain 
Table 2. AERONET daily mean $\mathrm{AOD}^{500}, \mathrm{AE}^{440 / 675}$ and $\mathrm{LR}^{\mathrm{AERONET}}$ (see text for details) for the overall dust tracking monitored period (ND denotes no data available).

\begin{tabular}{|c|c|c|c|c|c|c|c|c|c|}
\hline \multirow{2}{*}{$\begin{array}{l}\text { Site } \\
\text { March } 2008\end{array}$} & \multicolumn{3}{|c|}{ Santa Cruz de Tenerife (SCO-AEMET) } & \multicolumn{3}{|c|}{ "El Arenosillo" (ARN-INTA) } & \multicolumn{3}{|c|}{ Granada (GRA-UGR) } \\
\hline & AOD & $\mathrm{AE}$ & LR (sr) & AOD & $\mathrm{AE}$ & LR (sr) & AOD & $\mathrm{AE}$ & LR (sr) \\
\hline 11 & $0.12 \pm 0.01$ & $0.7 \pm 0.1$ & $40 \pm 8$ & $0.05 \pm 0.01$ & $1.0 \pm 0.1$ & $46 \pm 6$ & $0.09 \pm 0.01$ & $1.8 \pm 0.3$ & $59 \pm 5$ \\
\hline 12 & ND & ND & ND & $0.06 \pm 0.01$ & $1.3 \pm 0.3$ & $45 \pm 5$ & $0.09 \pm 0.05$ & $1.9 \pm 0.3$ & $51 \pm 10$ \\
\hline 13 & $0.48 \pm 0.11$ & $0.3 \pm 0.1$ & $50 \pm 0$ & $0.08 \pm 0.01$ & $1.1 \pm 0.3$ & ND & $0.10 \pm 0.03$ & $1.1 \pm 0.3$ & ND \\
\hline 14 & $0.42 \pm 0.03$ & $0.4 \pm 0.0$ & $59 \pm 4$ & $0.41 \pm 0.02$ & $0.2 \pm 0.0$ & $57 \pm 0$ & $0.60 \pm 0.28$ & $0.3 \pm 0.2$ & $48 \pm 3$ \\
\hline 15 & $0.28 \pm 0.03$ & $0.3 \pm 0.0$ & $60 \pm 7$ & $0.09 \pm 0.02$ & $1.0 \pm 0.3$ & $43 \pm 12$ & $0.12 \pm 0.01$ & $1.6 \pm 0.0$ & $76 \pm 17$ \\
\hline 16 & $0.32 \pm 0.03$ & $0.3 \pm 0.0$ & $48 \pm 6$ & ND & ND & ND & $0.08 \pm 0.03$ & $1.7 \pm 0.1$ & $57 \pm 13$ \\
\hline 17 & $0.26 \pm 0.04$ & $0.7 \pm 0.1$ & $32 \pm 4$ & ND & ND & ND & $0.13 \pm 0.01$ & $1.1 \pm 0.1$ & ND \\
\hline 18 & $0.14 \pm 0.00$ & $0.7 \pm 0.0$ & ND & $0.10 \pm 0.01$ & $1.1 \pm 0.1$ & $39 \pm 1$ & $0.09 \pm 0.01$ & $1.9 \pm 0.3$ & $55 \pm 5$ \\
\hline 19 & $0.09 \pm 0.01$ & $1.2 \pm 0.1$ & ND & $0.07 \pm 0.00$ & $0.9 \pm 0.0$ & ND & $0.15 \pm 0.01$ & $1.8 \pm 0.3$ & ND \\
\hline
\end{tabular}

Table 3. AERONET fine-to-total mode ratio $\left(\mathrm{V}_{\mathrm{F} / \mathrm{T}}^{\mathrm{AERONET}}\right)$ and effective radius $\left(r_{\text {eff }}^{\mathrm{AERONET}}\right.$ ) (in $\left.\mu \mathrm{m}\right)$ for the total $(\mathrm{T})$, fine (f) and coarse $(\mathrm{c})$ modes (SD denotes standard deviation).

\begin{tabular}{lllllllll}
\hline \multicolumn{4}{c}{ "El Arenosillo" (ARN-INTA) } & \multicolumn{3}{c}{ Granada (GRA-UGR) } \\
\hline & $\mathrm{V}_{\mathrm{F} / \mathrm{T}}^{\text {AERONET }}$ & $r_{\text {eff }}^{T}(\mathrm{SD})$ & $r_{\mathrm{eff}}^{f}(\mathrm{SD})$ & $r_{\text {eff }}^{c}(\mathrm{SD})$ & $\mathrm{V}_{\mathrm{F} / \mathrm{T}}^{\text {AERONET }}$ & $r_{\text {eff }}^{T}(\mathrm{SD})$ & $r_{\text {eff }}^{f}(\mathrm{SD})$ & $r_{\text {eff }}^{c}(\mathrm{SD})$ \\
Dusty & $0.08(*)$ & $0.94(*)$ & $0.16(*)$ & $1.69(*)$ & $0.08(0.01)$ & $1.01(0.05)$ & $0.19(0.01)$ & $1.62(0.01)$ \\
Non-dusty & $0.24(0.12)$ & $0.54(0.11)$ & $0.15(0.02)$ & $1.72(0.09)$ & $0.49(0.05)$ & $0.27(0.06)$ & $0.14(0.02)$ & $1.99(0.06)$ \\
\hline
\end{tabular}

(*) Just one value is available.

high whereas those observed over ARN and GRA sites would decrease, as confirmed by results shown in following sections. The situation is similar on 16 March.

On 17-19 March a reinforced Western flow is observed over both ARN and GRA sites at all altitude levels. Regarding SCO station, a change in the synoptic maps is registered for this period. The high system at $700 \mathrm{hPa}$ over Mauritania slowly moves westwards, the Azores high system is observed at its normal position at $925 \mathrm{hPa}$ while a low pressure system over the Northwestern Iberian Peninsula is moving to the South. This meteorological scenario produces a meridional flow over the Canary Islands resulting in a sharp decrease of dust content over SCO.

In summary, the meteorological situation provides optimal conditions for dust intrusion occurrence over the geographical area under study during the analyzed period.

\section{Results and discussion}

A case study of the medium-range scale transport monitoring of a dust plume describing an Atlantic arch and passing progressively over three Spanish stations is carried out in this work. The synergetic use of lidar observations and surface in-situ measurements together with AERONET data retrievals and HYSPLIT backtrajectory analysis is performed to evaluate potential changes occurred in the optical and microphysical properties of that dust plume. Dust particle de- position impact on surface once it arrives at and crosses the Southern Iberian Peninsula is also examined.

\subsection{Saharan dust intrusion identification}

\subsubsection{Evidence of dust signature}

The dust event has been monitored from 11 to 19 of March 2008 over all three stations. According to the dusty conditions criteria adopted (see Sect. 3.3), a 4-day long dust event (13-16 March) over SCO site and a linked short 1-day dust episode (14 March) over both ARN and GRA stations are found. Daily mean $\mathrm{AOD}^{500}$ and $\mathrm{AE}^{440 / 675}$ are shown in Fig. 3a and b, respectively (dusty periods are marked by light- and dark-shaded areas over SCO and ARN/GRA sites, respectively).

High (13-14 March) and moderate (15-16 March) $\mathrm{AOD}^{500}$ values are found over SCO site. Non-dusty conditions with low $\mathrm{AOD}^{500}(<0.15)$ and high $\mathrm{AE}^{440 / 675}(>0.5)$ values are observed just before and after this dusty monitored period in each station. These $\mathrm{AOD}^{500}$ and $\mathrm{AE}^{440 / 675}$ values together with AERONET-derived columnar-integrated LR $^{\text {AERONET }}$ (see Eq. 1) are also shown in Table 2 for each station. Therefore, AERONET data confirm the dust intrusion signature: high $(>0.35) /$ low $(<0.15) \mathrm{AOD}^{500}$ together with low $(<0.5) /$ high $(>0.5) \mathrm{AE}^{440 / 675}$ values are found for those dusty/non-dusty days over all three stations. 

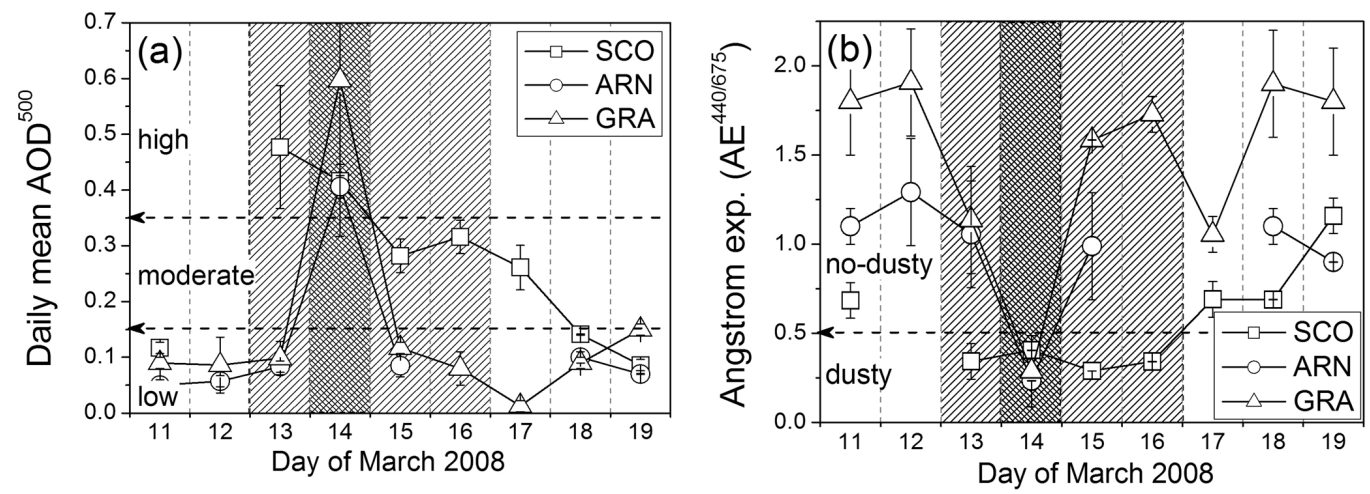

Fig. 3. (a) Daily mean $A O D$ at $500 \mathrm{~nm}\left(\mathrm{AOD}^{500}\right)$ and (b) Ångström exponent (AE ${ }^{440 / 675}$ ) for the three stations (see legend). Dusty periods are marked by light- and dark-shaded areas over SCO and ARN/GRA sites, respectively.
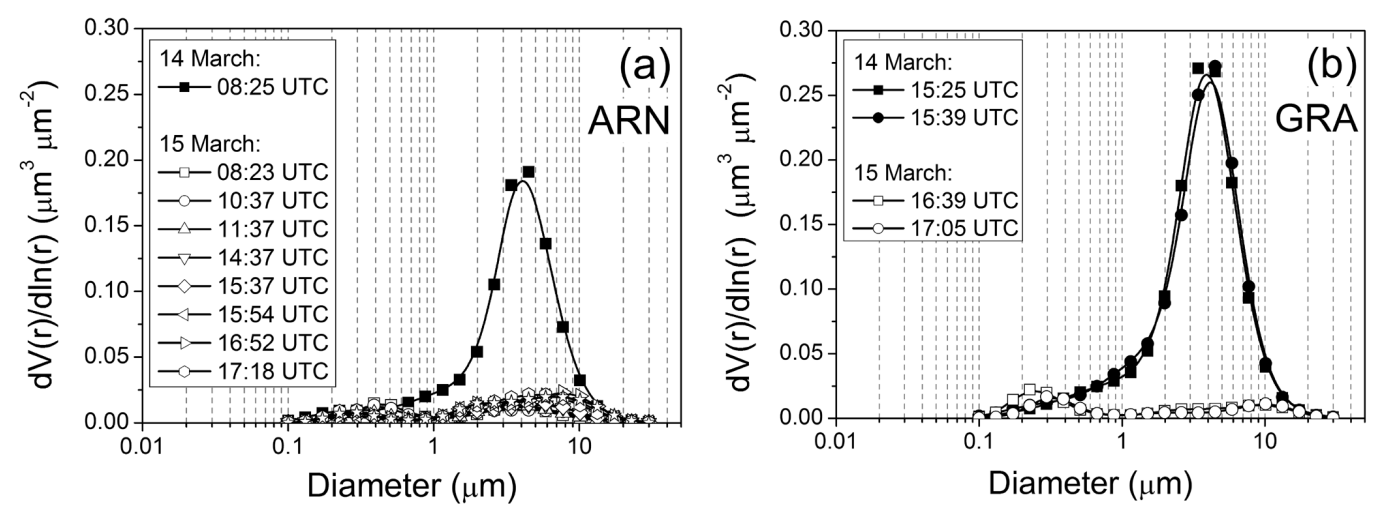

Fig. 4. AERONET columnar-integrated volume size distributions (VSD ${ }^{\text {AERONET }}$ ) at available times on 14 March (dusty day, full symbols) and 15 March (non-dusty day, open symbols) in ARN (a) and GRA (b) sites.

The impact of the mineral dust over the South of the Iberian Peninsula on 14 March is also observed from AERONET columnar-integrated size distributions $\left(\mathrm{VSD}^{\mathrm{AERONET}}\right)$. The available VSD ${ }^{\mathrm{AERONET}}$ for the dusty (14 March) and non-dusty (15 March) days in ARN and GRA sites are shown in Fig. 4a and b, respectively, and the ratio of the fine-to-total mode of the VSD ${ }^{\text {AERONET }}\left(\mathrm{V}_{\mathrm{F} / \mathrm{T}}^{\mathrm{AERONET}}\right)$ and the effective radius $\left(r_{\text {eff }}^{\mathrm{AERONET}}\right)$ for the total, fine and coarse modes of those VSD ${ }^{\text {AERONET }}$ are shown in Table 3. A $\mathrm{V}_{\mathrm{F} / \mathrm{T}}^{\mathrm{AERONET}}$ value of 0.08 is found for the dusty case in both stations, highlighting a predominance of coarse mode particles over the total distribution (see Fig. 4). In addition, the typical downward trend of the $r_{\text {eff }}^{\text {AERONET }}$ for the coarse mode during dusty episodes (Noh et al., 2008; Prats et al., 2008) is also observed in both sites, being more significant in the GRA case.

\subsubsection{Medium-range transport of dust plumes}

The origin and pathways of those dust plumes as identified over SCO site and later on ARN and GRA stations are examined by backtrajectory analysis. Five-day air masses backtrajectories are calculated by using HYSPLIT model at 3 altitudes (see Sect. 3.4) over each station for the overall period from 11 to 16 of March 2008. Those aerosol scenarios are confirmed over the area under study with additional valuable information on the dust plume tracking. For simplicity, days representative of both non-dusty and dusty scenarios in each station have been selected: 11, 13 and 14 March 2008. Figure 5 shows 5-day backtrajectories ending at SCO (square line), ARN site (triangle line) and GRA (circle line) sites for these selected days.

All air masses, independently on the altitude and site, arrive mostly from the ocean in non-dusty days. However, those arriving at $1500 \mathrm{~m}$ height over ARN and GRA stations had previously crossed the Iberian Peninsula for 6-9h (see Fig. 5d and e), carrying a small aerosol (ru$\mathrm{ral} /$ continental) contribution $(\mathrm{AOD}<0.1)$ as clearly observed 


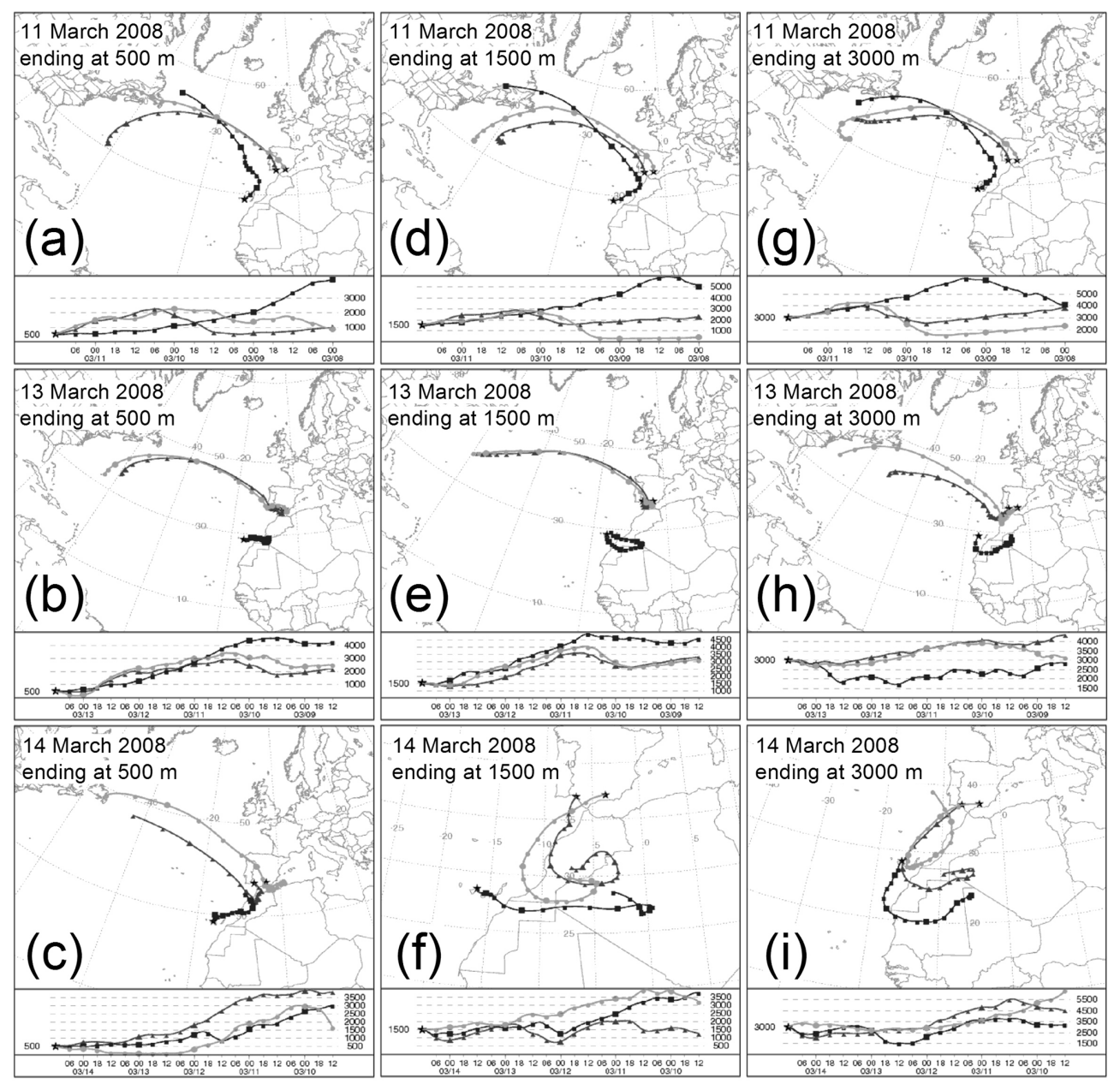

Fig. 5. HYSPLIT 5-day backtrajectories ending at 12:00 UTC over SCO (square black line), ARN site (triangle grey line) and GRA (circle black line) sites at different altitudes (a.g.1.): $500 \mathrm{~m}$ (a-c), $1500 \mathrm{~m}(\mathbf{d}-\mathbf{f})$ and $3000 \mathrm{~m}(\mathbf{g}-\mathbf{i})$. Figure panels correspond to three different dates as representative of both non-dusty and dusty conditions depending on each station (see legends inside each panel).

by lidar measurements taken over both ARN and GRA sites at that altitude (see next sections).

Under dusty conditions on 12-13 March, all air masses arriving at SCO site come from Saharan region. A day later (14 March), a change in wind direction in ARN and GRA stations is observed. In particular, from backtrajectory analysis, 3-km height air masses, representative of the FT, show evidence of Saharan dust arrival to the Iberian Peninsula stations after having crossed the Canary Islands (see Fig. 5h and i).

\subsection{Vertical monitoring of dust plume: lidar measurements}

\subsubsection{Dust layering structure}

Height-resolved backscatter is reported for each site (SCO, ARN and GRA) under non-dusty and dusty conditions. Dust backscatter hourly-averaged (1-h) profiles are only retrieved at discrete times because lidar data inversion is prevented by random cloud contamination for the overall observational period. Anthropogenic/marine aerosol contribution is also considered as a source of uncertainties introduced in that vertical dust characterization, if necessary.

\section{(a) SCO aerosol profiling}

Non-dusty conditions are found over SCO site before and after the 4-day Saharan dust intrusion (13-16 March 2008) as indicated by AERONET data and HYSPLIT backtrajectory analysis (see Sect. 5.1). Daily mean $\mathrm{AOD}^{500}$ values were below the defined threshold of 0.15 with the $\mathrm{AE}^{440 / 675}$ ranging from 0.7 to 1.2 in these non-dusty days of the overall monitored period. This atmospheric state represents typical clean marine conditions over coastal sites (i.e., Dubovik et al., 2002b; Cattrall et al., 2005) like SCO station. In particular, the non-dusty case over SCO site on 11 March is 


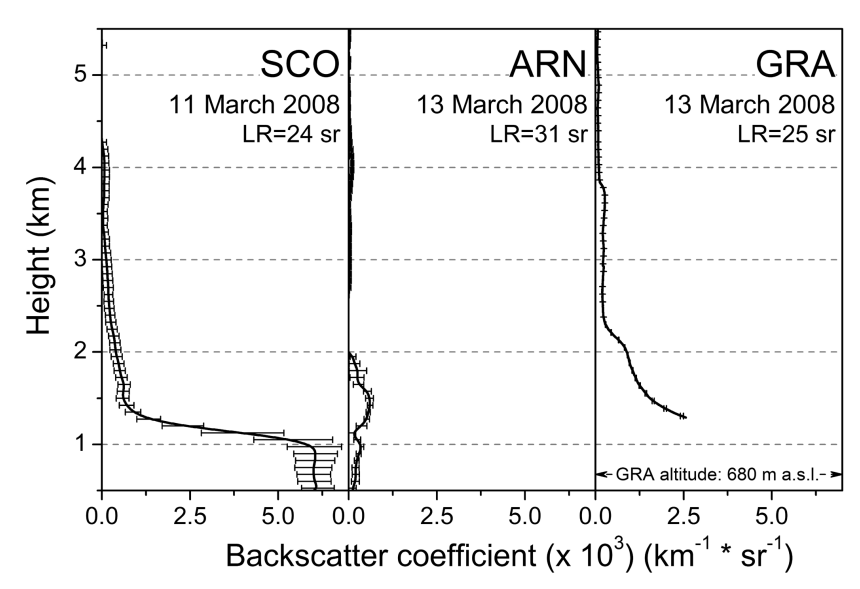

Fig. 6. Height-resolved backscatter coefficients at 12:00 UTC (1$\mathrm{h}$ averaged profiles) for non-dusty conditions over SCO site (left), and ARN (centre) and GRA (right) stations (GRA station altitude: $680 \mathrm{~m}$ a.s.1.). Both lidar-retrieved LR and date of measurements are indicated in each panel.

examined. Aerosol profiling shows a layer confined in the marine boundary layer (MBL) at heights lower than $1.2 \mathrm{~km}$. Vertical backscatter coefficients at 12:00 UTC (1-h averaged profiles with error bars) over SCO site are shown in Fig. 6left.

Regarding the fact that SCO station is a coastal site, marine contribution to aerosol profiling is ubiquitous. Therefore, a two-component aerosol system in a well differentiated two-layer atmosphere is considered for lidar data retrieval (Ansmann, 2006). Two aerosol dusty scenarios are proposed: 1) a 'pure-dust' scenario (PDS), where dust particles are assumed as the principal aerosol component present in the overall atmosphere (no aerosol-type discrimination), and 2) a "mixed-dust" scenario (MDS), where a mixture of marine and dust particles are supposed to be present in the boundary layer (BL), and only dust in the free troposphere (FT). By this procedure, as reported by CórdobaJabonero et al. (2010), the marine aerosol contribution can be considered as a source of uncertainties introduced in that vertical dust characterization by data inversion processing.

By applying this procedure, in particular on 13 March, the day selected as representative for the 4-day dusty event over SCO site, a multilayered structure slightly varying along the day is observed in each dusty scenario. A higher dust contribution at BL heights for the PDS than MSD case, as expected by those inversion input conditions, is found. Dust intrusion top is reached at around $4.5 \mathrm{~km}$ height, with the principal dust contribution, a $2.5 \mathrm{~km}$ width layer, extended from 1.5 to $4.0 \mathrm{~km}$ height. In this layer a dust enhanced peak is observed at around $3 \mathrm{~km}$ height during morning hours. Lidar-retrieved height-resolved dust backscatter coefficients (with error bars) at selected averaged times for each dusty scenario are shown in Fig. 7.
As expected, when AERONET AOD constraint is applied for data retrieval (see Sect. 3.1.3), dust profiling shows an enhancement at FT altitudes $(>1.2 \mathrm{~km})$ and a decrease at BL heights $(<1.2 \mathrm{~km})$ for the MDS case in comparison to the PDS one. In particular on 13 March, the daily mean dust contribution to the total AOD at FT heights over SCO was $69 \% \pm 2 \%$ for the MDS case, larger than that $58 \% \pm 3 \%$ obtained for the PDS. These results highlight the importance of the aerosol scenario selected for lidar data retrieval (Córdoba-Jabonero et al., 2010). Accordingly, these results are also reflected in the retrieved LR data, as exposed in the next section.

\section{(b) ARN and GRA aerosol profiling}

A similar analysis of the lidar measurements is performed for both ARN and GRA sites. Aerosol non-dusty conditions are found over both ARN and GRA sites just before and after the 1-day Saharan dust intrusion (14 March 2008) as indicated by AERONET data and HYSPLIT backtrajectory analysis (see Sect. 5.1). The case for 13 March is examined as an example of non-dusty conditions. The vertical backscatter coefficients at noon (1-h averaged profiles with error bars) over ARN and GRA sites are shown in Fig. 6-centre and Fig. 6right, respectively. Aerosol vertical structure over ARN station differs from that obtained over SCO site: no highly significant presence of BL aerosols is observed. A small aerosol contribution is only found at around $1500 \mathrm{~m}$ a.s.l. This result is in agreement with the previous backtrajectory analysis. Air masses arriving at $1500 \mathrm{~m}$ (triangle line in Fig. 5e) had previously crossed the Peninsula for a few hours, likely carrying a small aerosol (anthropogenic/continental) contribution $(\mathrm{AOD}<0.1$, see Table 2) at these altitudes. Similar results are also found for GRA station (circle line in Fig. 5e), but in this case, the continental contribution is even smaller. Regarding the GRA profiles, the higher altitude of this station (680 $\mathrm{m}$ a.s.l.) must be taken into account for lidar measurements analysis.

Lidar backscatter coefficients retrieval is also performed for the 1-day dusty episode (14 March 2008) at a few discrete times due to cloud contamination. Figure 8 shows the 1-h averaged profiles with error bars for ARN (Fig. 8centre) and GRA (Fig. 8-right) (SCO profiling is also shown for comparison purposes). Examining the aerosol backscatter, dust structure presents an extended layer ranging from 2.0 to $4.5 \mathrm{~km}$ height, being more remarkable for ARN site. In this situation, with no highly significant presence of BL aerosols, only one of the two previously proposed aerosol dusty scenarios is considered for data retrieval: the PDS case with just a little anthropogenic/marine contribution at BL altitudes. Unlike SCO site, where a multilayered dust structure extending from BL to FT levels was observed, dust particles over the Iberian Peninsula are mostly confined in a single layer of $2.0-2.5 \mathrm{~km}$ thick lying in the FT. 
Table 4. LR values (at $532 \mathrm{~nm}$ ) reported by several reference works together with other information for aerosol-type discrimination criteria.

\begin{tabular}{|c|c|c|c|c|c|}
\hline Aerosol type & LR (sr) & $\mathrm{AE}$ & Observations & $\begin{array}{l}\text { Observational } \\
\text { (Campaign) }\end{array}$ & References \\
\hline \multirow[t]{4}{*}{ Marine } & $<40$ & $>1.5$ & LIDAR & \multirow{4}{*}{$\begin{array}{l}\text { Mediterranean } \\
\text { North Atlantic (ACE-2) }\end{array}$} & Balis et al. $(2004)^{\mathrm{a}}$ \\
\hline & $28 \pm 5$ & $0.7 \pm 0.4$ & AERONET & & Cattrall et al. $(2005)^{\mathrm{b}}$ \\
\hline & $23 \pm 3$ & & LIDAR & & Müller et al. (2007) \\
\hline & $20 \pm 6$ & & Satellite (CALIPSO) & & Omar et al. (2009) \\
\hline \multirow{3}{*}{$\begin{array}{l}\text { Mixing } \\
\text { (dust/no-dust } \\
\text { particles) }\end{array}$} & $38 \pm 10$ & $0.5-1.0$ & LIDAR & \multirow{3}{*}{$\begin{array}{l}\text { Southern Italy } \\
\text { Mediterranean }\end{array}$} & Tomasi et al. (2003) \\
\hline & $40-60$ & $0.5-1.5$ & LIDAR & & Balis et al. $(2004)^{\mathrm{a}}$ \\
\hline & $65 \pm 20$ (polluted dust) & & Satellite (CALIPSO) & & Omar et al. (2009) \\
\hline \multirow{5}{*}{ Dust } & $>60$ & $<0.5$ & LIDAR & \multirow{5}{*}{$\begin{array}{l}\text { Mediterranean } \\
\text { Sahara (SAMUM) } \\
\text { Sahara (EARLINET) }\end{array}$} & Balis et al. (2004) ${ }^{\mathrm{a}}$ \\
\hline & $42 \pm 4$ & $0.1 \pm 0.1$ & AERONET & & Cattrall et al. $(2005)^{\mathrm{b}}$ \\
\hline & $55 \pm 5$ & $0.2 \pm 0.2$ & LIDAR & & Müller et al. (2007) \\
\hline & $59 \pm 11$ & $0.5 \pm 0.5$ & LIDAR & & Müller et al. (2007) \\
\hline & $40 \pm 12$ & & Satellite (CALIPSO) & & Omar et al. (2009) \\
\hline
\end{tabular}

${ }^{\text {a }}$ At $355 \mathrm{~nm} ;{ }^{\text {b }}$ At $550 \mathrm{~nm}$

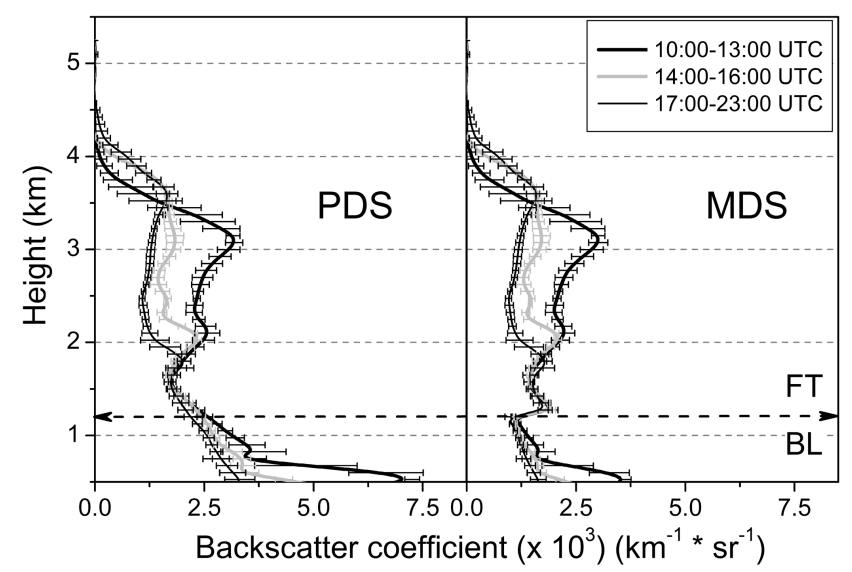

Fig. 7. Height-resolved backscatter coefficients under dusty conditions over SCO site (13 March 2008) for the "pure-dust scenario" (PDS) (left) and the "mixed-dust scenario" (MDS) (right) at selected averaged times (see legend).

Enhancement of aerosols in the mentioned layer one day after the air masses crossed Tenerife area confirms together the columnar-integrated measurements (see Sect. 5.1.1) and backtrajectory analysis (see Sect. 5.1.2) that the three stations were affected by the same Saharan air masses. That dust layer at $3.0-3.5 \mathrm{~km}$ height over the Southern Iberian Peninsula as detected by lidar instrumentation at both ARN and GRA stations is directly related to that dust plume observed over Tenerife at $3 \mathrm{~km}$ height, as stated before by backtrajectory analysis (see Sect. 5.1, and in particular Fig. 5i). Moreover, GRA site also presents an aerosol contribution at heights lower than $2.0 \mathrm{~km}$. This is likely due to local anthropogenic aerosol sources. This result is also reflected in the higher AOD values registered in GRA site compared to those measured at the rural ARN station (see Table 2).

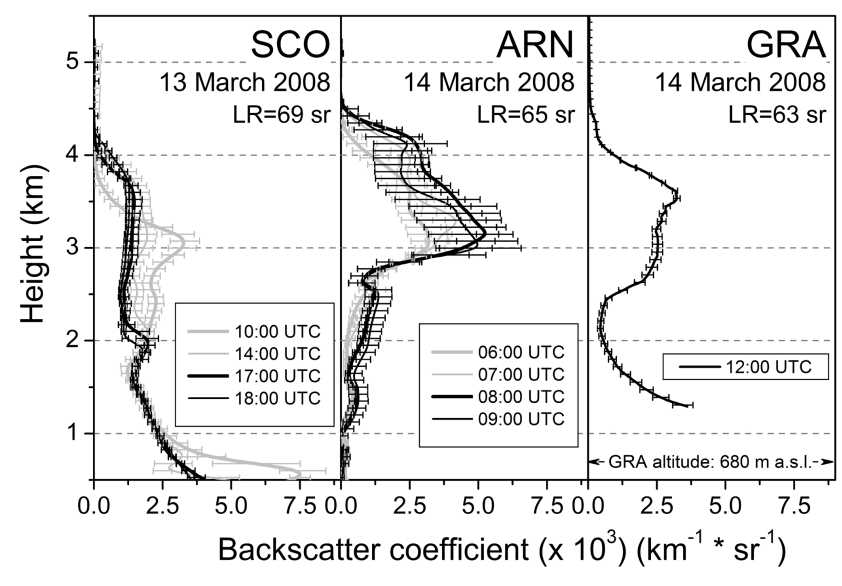

Fig. 8. Height-resolved backscatter coefficients (1-h averaged profiles) at discrete times (see legend) under dusty conditions over SCO site (left), ARN (centre) and GRA (right) stations. Both lidarretrieved $L R$ and date of measurements are indicated in each panel.

\subsubsection{Extinction-to-backscatter ratio (LR) retrievals}

Lidar-retrieved LR (extinction-to-backscatter ratio) values, considering AERONET daily mean AOD as a constraint condition (see Sect. 3.1.3 for data processing details), are obtained for each aerosol scenario: $\mathrm{LR}=24 \mathrm{sr}, 31 \mathrm{sr}$ and $25 \mathrm{sr}$ under non-dusty conditions, and LR $=52 \mathrm{sr}, 65 \mathrm{sr}$ and $63 \mathrm{sr}$ under PDS conditions, for SCO, ARN and GRA sites, respectively. In the MDS case, a LR value of $69 \mathrm{sr}$ is retrieved for SCO station when a $\mathrm{LR}=35 \mathrm{sr}$ is fixed at BL heights $(<1.2 \mathrm{~km})$. This former value is assumed as representative for the mixed state (mixture of marine and dust particles) of the SCO boundary layer for elastic lidar data inversion (AERONET AOD constrain) (Córdoba-Jabonero et al., 2010). These results are in good agreement with previously 


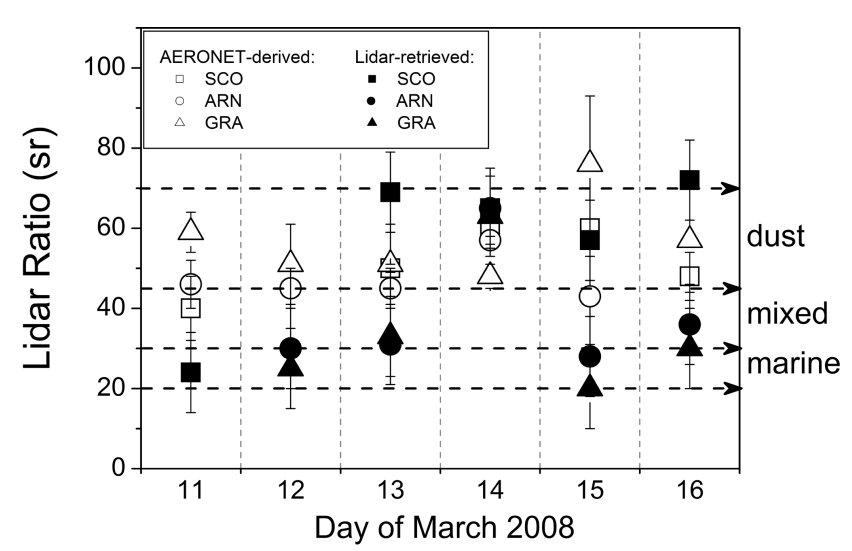

Fig. 9. Lidar-retrieved LR (extinction-to-backscatter ratio) values together with those columnar-integrated AERONET-derived ones (see Table 2). LR ranges as adopted for aerosol-type discrimination are also marked (shaded arrows).

reported values based on lidar measurements of dust intrusions (i.e, Müller et al., 2003, 2007; Mona et al., 2006; Papayannis et al., 2008; Guerrero-Rascado et al., 2009).

Both AERONET-derived (see Table 2) and lidar-retrieved sets of LR values obtained for the overall monitored period at each station are shown in Fig. 9, where also the LR ranges adopted for different aerosol types are marked (dashed arrows): marine (20-30 sr), mixed (30-45 sr) and dust (45-70 sr). This LR criterion for aerosol-type discrimination is based on results from different previous works, including both lidar and AERONET retrievals. A summary of the LR values obtained by those reference works together with other information is shown in Table 4. CALIPSO (Cloud-Aerosol Lidar and Infrared Pathfinder Satellite Observation, http://www-calipso.larc.nasa.gov) LR-defined values are also included (Omar et al., 2009), showing an uncertainty of $30 \%$ as assumed (Liu et al., 2005) according to ground-based lidar measurements comparison (Voss et al., 2001; Liu et al., 2002).

Independently on the observational site, AERONETderived LR values (open symbols in Fig. 9) are, in general, overestimated under non-dusty conditions, but underestimated in the presence of dust in comparison with the lidar-retrieved ones (solid symbols, see legend in Fig. 9). This AERONET LR underestimation under dusty conditions is also observed by other authors (i.e., Müller et al., 2003, 2007). LR values depend on chemical composition (refractive index), particle shape and size distribution. Therefore these differences found between both datasets for dust, non-spherical particles, may in part be caused by an insufficient understanding of the light-scattering model (Dubovik et al., 2002a 2006), highly shape-dependent, which is used in the AERONET data inversion algorithm. Müller et al. (2010b) found a good agreement of the lidar ratio at visible wavelengths derived from lidar and sun-photometry mea- surements when a more realistic and improved dust model (Dubovik et al., 2006) is used instead.

The AERONET LR overestimation under non-dusty conditions is also obtained by Landulfo et al. (2003) at São Paulo area, where no-dust (marine, continental, urban and biomass burning) aerosol case studies were only present. These results indicate the special features of dust particles in order to assess its impact into the radiative balance of the atmosphere, among other questions, in dependence on the methods/techniques used for dust characterization.

Important differences in LR values among the three stations are not found. This result can reflect that dust particles travelling in the same air mass plume have conserved their optical properties during that medium-range pathway. The small differences found in the dust properties measured in these stations can be associated to aging processes (chemical transformations along the tracking) and size distribution variations.

\subsection{Potential impact on surface of the medium-range transported dust plume once over the Southern Iberian Peninsula}

\subsubsection{Surface air masses analysis}

Lidar measurements showed that the dust plume is travelling between 2.5 and $4.5 \mathrm{~km}$ over the Iberian Peninsula, as observed at ARN and GRA stations on 14 March, after crossing through the Canary Islands a day before, and in particular SCO station. HYSPLIT backtrajectories clearly show a Saharan origin of these dust air masses (see Fig. 5). They were following an Atlantic arch through the Canary Islands favoured by the meteorological situation in that area before reaching the Southern Iberian Peninsula. In order to get a better picture on what is going on below that Saharan dust plume at rather lower heights, a brief analysis of the origin of the air masses arriving at closest-to-surface altitudes over ARN and GRA stations is performed.

Dust plumes at BL over ARN and GRA sites have been analyzed by using HYSPLIT 5-day backtrajectories at $500 \mathrm{~m}$ a.g.l. Results indicate that air masses come directly from the Northern and Northwestern African continent, influencing ARN station on 14 March from 06:00 to 14:00 UTC and from 14 March at 15:00 UTC to 15 March at 09:00 UTC, respectively. In the case of GRA site, they also arrive from Northern Africa from 14 March at 14:00 UTC to 15 March at 10:00 UTC but after previously crossing the Iberian Peninsula. After 15 March at 06:00 UTC air masses do not come from desert areas. Those air mass backtrajectories ending at $500 \mathrm{~m}$ a.g.l. are shown in Fig. 10 over both ARN (triangle line) and GRA (square line) sites.

In addition, air masses ending at ARN site have been crossing the desert area for a longer time and have arrived from a higher height (about $1500 \mathrm{~m}$ a.g.l.) than those ending at GRA site (see Fig. 10a and b). According to 


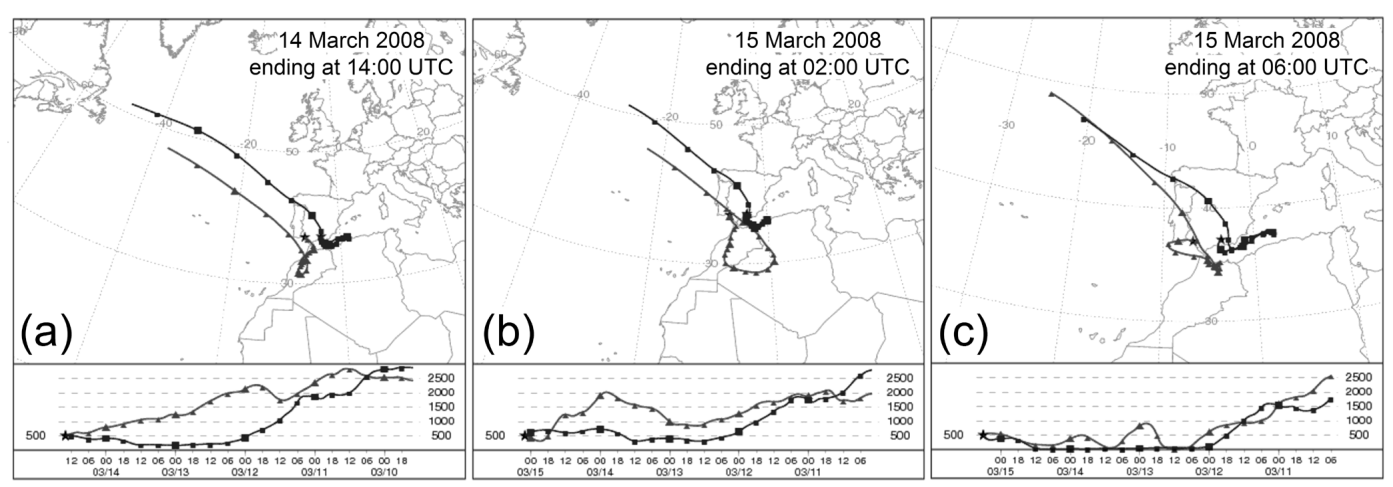

Fig. 10. HYSPLIT 5-day backtrajectories ending at $500 \mathrm{~m}$ height a.g.l. over both ARN (triangle line) and GRA (square line) sites. Figure panels correspond to three representative dates and times for that dust episode: (a) 14 March at 14:00 UTC, (b) 15 March at 02:00 UTC, and (c) 15 March at 06:00 UTC.
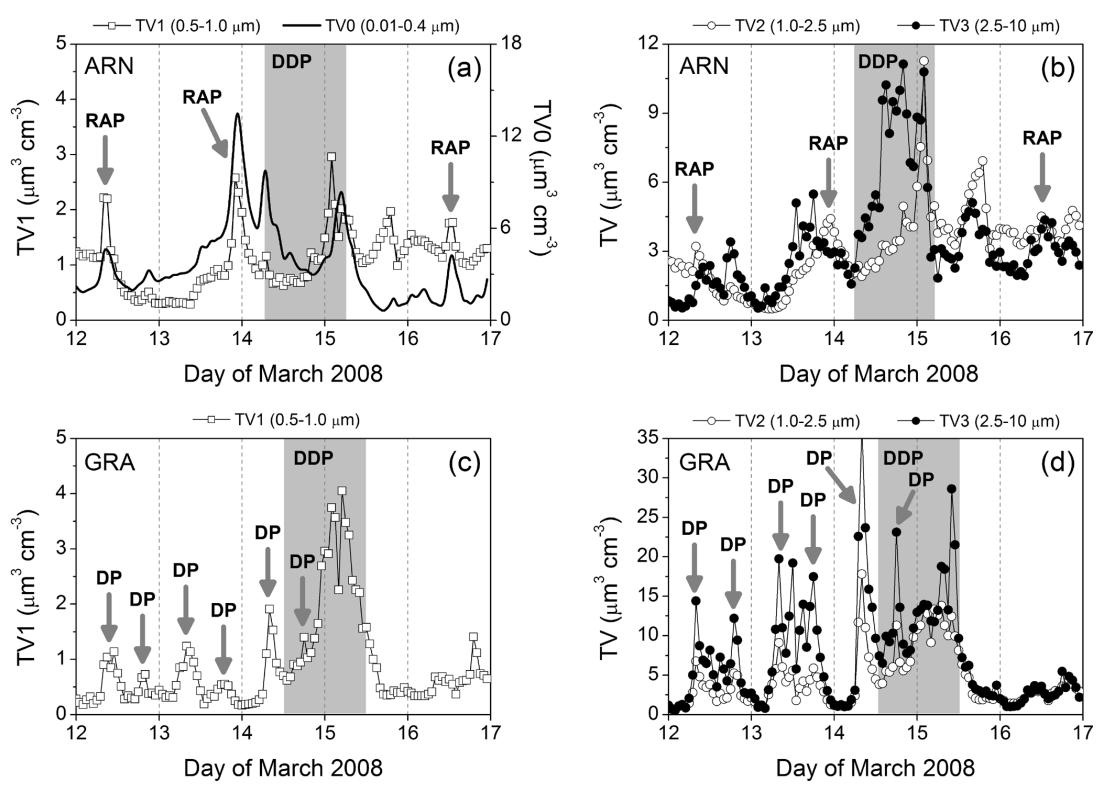

Fig. 11. Temporal evolution of the total volume (TV) particle concentration (hourly integrated) for four discrete size ranges: $0.01-0.4 \mu \mathrm{m}$

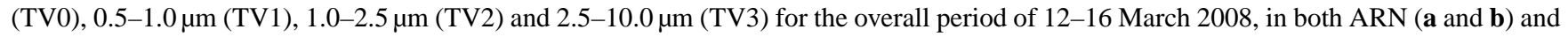
GRA (c and d) sites. Selected aerosol episodes are marked by grey arrows (Regional Anthropogenic Plume, RAP, and Diurnal Pattern, DP) and shaded area (Desert Dust Plume, DDP) in each case.

backtrajectories, these air masses seem not to be related to the upper 3-km height dust plume. However, surface in-situ measurements must be examined to confirm this preliminary result and the potential dust impact on surface.

\subsubsection{Surface in-situ observations: ground-level measurements}

Both size-resolved and optical properties at ground level are investigated with the aim to evaluate the impact of dust aerosol over ARN and GRA sites. Comparison with the AERONET columnar-integrated data (Sect. 5.1.1, see Fig. 4) is also analysed.

\section{(a) Size-resolved measurements}

Particle volume size distribution has been used in this work since this magnitude, better than number or surface, represents the ground-level sediment mass. Although the particle number is small, coarse mode is a significant or even dominant contribution to the total loading. Temporal evolution of the total volume particle concentration (TV) is presented for four discrete size ranges: $0.01-0.4 \mu \mathrm{m}$ (TV0), 0.5$1.0 \mu \mathrm{m}$ (TV1), 1.0-2.5 $\mu \mathrm{m}$ (TV2) and 2.5-10.0 $\mu \mathrm{m}$ (TV3) for the overall period of 12-16 March 2008 in both ARN (see Fig. 11a and b) and GRA (see Fig. 11c and d) sites (no TV0 data are available in GRA station). Three different kinds of 
aerosol episodes are selected to illustrate the aerosol particle size-resolved features: (1) the Regional Anthropogenic Plume (RAP) episode, presenting an increase of volume concentration predominantly for sub-micrometer particles (TV0 and TV1); (2) the Desert Dust Plume (DDP) episode, with a predominance of micrometer-size $(>1 \mu \mathrm{m}$, i.e., TV2 and TV3 ranges) particles over the total volume concentration; and 3) the Diurnal Pattern (DP) scenario, characterized by local environmental conditions controlling the particle sources of sub- (TV1) and micrometer- (TV2 and TV3) sizes. These selected aerosol episodes are marked by grey arrows (RAP and DP) and dashed areas (DDP) in Fig. 11.

RAP episodes appear in ARN site (Fig. 11a and b) when the wind was blowing from Northern direction, where a cement factory is located at about $30 \mathrm{~km}$ from this station. The strongest RAP episode is observed from the second half of the day 13 March to the next early morning. During this episode, both TV0 and TV1 concentrations increase by 2.8 and 3.5, respectively. At the same time, TV2 concentration shows the same behaviour but at a smaller scale.

During DP episodes in GRA station, the volume concentration presents a clear diurnal pattern with two local maxima around 08:00 UTC and 19:00 UTC during working days (see Fig. 11c and d), caused by local traffic and atmospheric boundary layer activities, as also indicated in previous published works (Lyamani et al., 2008, 2010). The early morning maximums of TV1, TV2 and TV3 concentrations are $1.7 \pm 0.5,1.5 \pm 0.2$ and $1.3 \pm 0.3$ times on average higher, respectively, than their evening maximums. Morning DP event on 12 March is selected as representative of local traffic impact over volume size distributions in GRA site. TV1, TV2 and TV3 concentrations increase by 4.0, 4.6 and 7.0 times, respectively.

Therefore, DP episodes at GRA station and LP events at ARN site produce a similar impact on the concentration of submicrometer-size particles (TV1). However, DP episodes at GRA generate a higher effect on the concentration of micrometer-size particles than LP events at ARN. By comparison between both stations, TV1 concentrations are similar in both rural-coastal (ARN) and urban (GRA) environments. This result can be associated to marine aerosol presence over ARN site, and local anthropogenic particles in GRA station. Regarding TV2 and TV3 particles, their concentrations are higher in GRA site, with peak values at working days mainly related to re-suspended aerosols by road traffic.

The analysis of the DDP episode allows assessing the impact on surface and the duration of the Saharan dust intrusion plume examined in this work. A difference of $8 \mathrm{~h}$ on dust event detection is observed between both stations, as it is also observed by HYSPLIT backtrajectory analysis at ground level (see Sect. 5.3.1 and Fig. 10). That dust plume travelling coincides with the temporal evolution presented in Fig. 11, and therefore surface in-situ measurements confirm the DDP
Table 5. Date and starting and ending times together with the maximum and minimum TV concentration values as reached for each size range of the DDP episode in both ARN and GRA stations.

\begin{tabular}{|c|c|c|c|}
\hline TV range & $\begin{array}{l}\text { Day } \\
\text { Starting time }\end{array}$ & $\begin{array}{l}\text { Day } \\
\text { Ending time }\end{array}$ & $\begin{array}{l}\text { TV concentration } \\
\left(\mu \mathrm{m}^{3} \mathrm{~cm}^{-3}\right) \\
\text { Minimum- } \\
\text { Maximum }\end{array}$ \\
\hline \multicolumn{4}{|c|}{ ARN station } \\
\hline TV0 & $\begin{array}{l}\text { 15 March } \\
\text { 03:00 UTC }\end{array}$ & $\begin{array}{l}\text { 15 March } \\
\text { 09:00 UTC }\end{array}$ & $4.3-8.8$ \\
\hline TV1 & $\begin{array}{l}15 \text { March } \\
\text { 00:00 UTC }\end{array}$ & $\begin{array}{l}\text { 15 March } \\
\text { 09:00 UTC }\end{array}$ & $1.5-2.3$ \\
\hline TV2 & $\begin{array}{l}\text { 15 March } \\
\text { 00:00 UTC }\end{array}$ & $\begin{array}{l}\text { 15 March } \\
05: 00 \text { UTC }\end{array}$ & $5.3-10.6$ \\
\hline TV3 & $\begin{array}{l}\text { 14 March } \\
\text { 06:00 UTC }\end{array}$ & $\begin{array}{l}\text { 14 March } \\
\text { 03:00 UTC } \\
\text { RA station }\end{array}$ & $3.0-11.1$ \\
\hline TV0 & - & - & - \\
\hline TV1 & $\begin{array}{l}\text { 14 March } \\
\text { 14:00 UTC }\end{array}$ & $\begin{array}{l}15 \text { March } \\
\text { 12:00 UTC }\end{array}$ & $0.7-4.0$ \\
\hline TV2 & $\begin{array}{l}\text { 14 March } \\
\text { 14:00 UTC }\end{array}$ & $\begin{array}{l}\text { 15 March } \\
\text { 12:00 UTC }\end{array}$ & $3.9-13.8$ \\
\hline TV3 & $\begin{array}{l}\text { 14 March } \\
\text { 23:00 UTC }\end{array}$ & $\begin{array}{l}\text { 15 March } \\
\text { 12:00 UTC }\end{array}$ & $10.9-28.6$ \\
\hline
\end{tabular}

episode over both ARN and GRA stations at ground-level surface.

The highest impact of DDP episode over ARN station (see Fig. 11a and b) is observed on the TV3 concentration, from 14 March at 06:00 UTC to 15 March at 03:00 UTC. Persistent TV3 levels of about $10 \mu \mathrm{m}^{3} \mathrm{~cm}^{-3}$ are observed on 14 March at 14:00 UTC, when the air masses affecting ARN station are crossing at higher altitudes over Northwestern African continent (see Sect. 5.3.1). The highest TV1 and TV2 concentrations in ARN site were registered on 15 March at 00:00 UTC, $10 \mathrm{~h}$ later than TV3 maximum levels. During this episode, the TV1 and TV2 concentrations increase by a factor of 2 . The highest TV0 concentration in ARN is registered on 15 March at 03:00 UTC, $3 \mathrm{~h}$ later than TV3 highest levels, increasing by more than 2 times for this event. These fine particles belong to the DDP episode, since their enhancement and evolution coincide with that of TV3 particles and the wind was blowing from the Southwest (ocean direction) but not from the Northern direction, where the cement factory is placed. In the case of GRA DDP episode (see Fig. 11c and d), the TV 3 concentration reaches its maximum $9 \mathrm{~h}$ later than the TV1 and TV 2 concentrations are in their highest levels. A simplified chronology with the most relevant features of the DDP episode for each particle size range is shown in Table 5 for both ARN and GRA sites.

Comparing these results obtained in both stations, the highest impact of this DDP event on background concentration levels is observed in GRA site. These results agree with the backtrajectory analysis (see Sect. 5.3.1) showing that the air masses arriving at GRA station during this episode come 

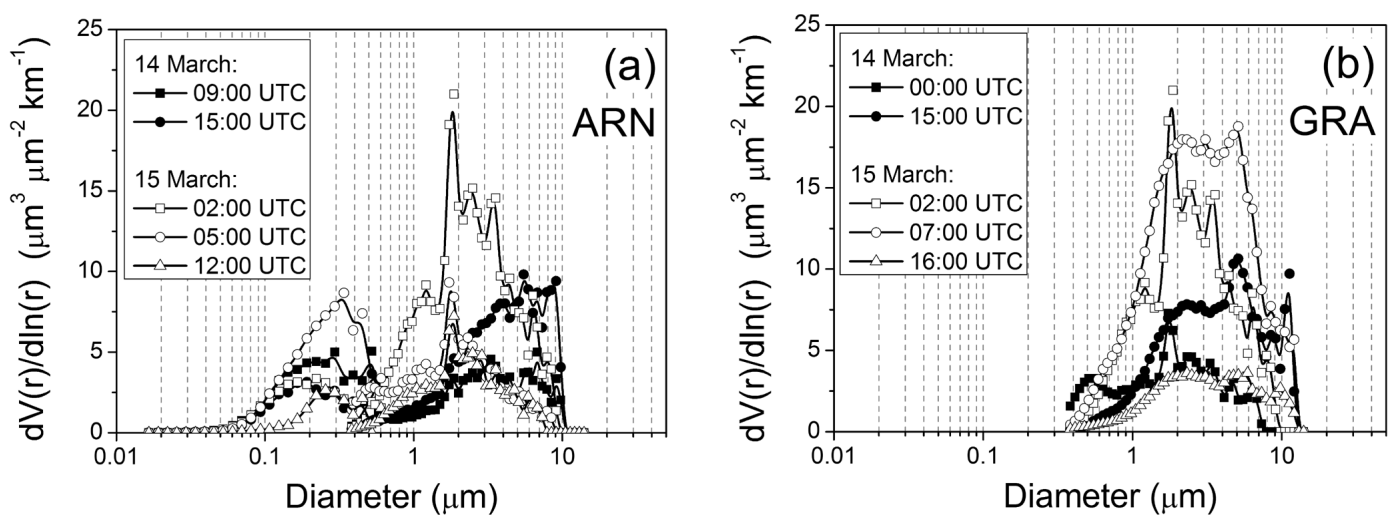

Fig. 12. Ground-level volume size distributions $\left(V_{S D}{ }^{\mathrm{GL}}\right.$ ) from in-situ measurements at selected times on 14 March (dusty day, full symbols) and 15 March (non-dusty day, open symbols) in ARN (a) and GRA (b) sites.

from rather lower heights, even touching the surface, than those reaching ARN site (from $1500 \mathrm{~m}$ height). This result is also supported by lidar measurements showing no dust incidence from around $1800 \mathrm{~m}$ height down to surface (see Fig. 8).

Regarding the temporal evolution of the TV particle concentrations during the DDP episode (see Table 5), differences are observed between both sites related to the deposition process. In ARN large particles are deposited on surface before the small ones, and TV2 concentration increase is detected at ground level with a 10-h delay with regard to the TV3 concentration. However, the maximum TV3 concentration in GRA station is detected with a 9-h delay in relation to TV2. This opposite result can be related to the gravitational deposition process in ARN from the 3-km height dust layer as observed by lidar measurements (see Sect. 5.2) whereas in GRA, particles at ground level are coming directly from the African continent. The first deposition behaviour corresponds to the fact that larger particles $(>2.5 \mu \mathrm{m})$ settle down faster than smaller ones $(<2.5 \mu \mathrm{m})$ by gravitational process, being then first detected in ARN site, while the second ones are associated to a slower horizontal velocity of sedimentation for large particles (TV3), arriving later at GRA station.

Selected particle volume size distributions (hourly averaged) at ground level (VSD ${ }^{\mathrm{GL}}$ ) under dusty and non-dusty conditions are presented in Fig. 12a and b for ARN and GRA sites, respectively. The VSD ${ }^{\mathrm{GL}}$ in ARN site have been smoothed due to the high coarse mode data variability introduced by large statistical errors. As the event proceeds, deposition is shifting from coarse mode to fine mode. A representative $\mathrm{VSD}^{\mathrm{GL}}$ for the beginning of dust event can be observed on 14 March at 09:00 UTC in ARN site. Sedimentation of large particles takes place on 14 March at 15:00 UTC (see Fig. 12a), with a coarse modal diameter estimation of about $7 \mu \mathrm{m}$. Few hours later, on 15 March at 02:00 UTC, the contribution of small $(<2.5 \mu \mathrm{m})$ particles increases, with fine and coarse modal diameters of $0.2 \mu \mathrm{m}$ and $2.2 \mu \mathrm{m}$, re- spectively. Finally, on 15 March at 05:00 UTC, VSD ${ }^{\mathrm{GL}}$ is characterized by the deposition of submicrometer particles, being the fine and coarse modal diameters of $0.35 \mu \mathrm{m}$ and $2.0 \mu \mathrm{m}$, respectively.

These four selected dusty distributions present a ratio of the fine-to-total mode of the $\mathrm{VSD}^{\mathrm{GL}}\left(\mathrm{V}_{\mathrm{F} / \mathrm{T}}^{\mathrm{GL}}\right)$ of $0.54,0.29$, 0.26 and 0.60 , respectively. Finally, VSD ${ }^{\mathrm{GL}}$ on 15 March at 12:00 UTC is representative of non-dusty conditions with modal diameters of $0.2 \mu \mathrm{m}$ and $2.3 \mu \mathrm{m}$ for the fine and coarse modes, respectively, and a $\mathrm{V}_{\mathrm{F} / \mathrm{T}}$ of 0.34 . $\mathrm{V}_{\mathrm{F} / \mathrm{T}}^{\mathrm{AERONET}}$ values of around 0.1, similar to those obtained for the VSD ${ }^{\text {AERONET }}$ on 14 March at 08:25 UTC (see Fig. 4 and Table 3), correspond to the presence of dust particles as based on previous results on columnar-integrated aerosol characterization in ARN site (Prats et al., 2008). According to the results obtained during the desert dust event analyzed in this work, the highest dust impact over ARN site occurs on 14 March at 15:00 UTC and 15 March 02:00 UTC when lower $\mathrm{V}_{\mathrm{F} / \mathrm{T}}$ are found, i.e. around 0.28 , a value higher than that 0.1 reported by Prats et al. (2008). This result highlights the underestimation provided by the columnar-integrated data to the fine mode particle contribution under dusty conditions in comparison with that obtained by surface in-situ measurements.

The VSD ${ }^{\mathrm{GL}}$ evolution over GRA site is shown in Fig. 12b, which is only evaluated by using APS system measurements (no instrumentation for particles $<0.4 \mu \mathrm{m}$ size detection is in GRA). Typical non-dusty VSD ${ }^{\mathrm{GL}}$ are found before $14 \mathrm{March}$ at 00:00 UTC and after 15 March at 19:00 UTC. During the first phase of the dusty episode, $\mathrm{VSD}^{\mathrm{GL}}$ presented an increase of micrometer-size particles, mainly within the TV2 particle range, as shown on 14 March at 19:00 UTC and 15 March at 02:00 UTC in Fig. 12b. A modal diameter of $1.8 \mu \mathrm{m}$ is obtained for these cases. The impact of large particles is represented for the $\mathrm{VSD}^{\mathrm{GL}}$ on 15 March at 07:00 UTC, with a modal diameter of $5.1 \mu \mathrm{m}$. In the course of the dust event, coarse mode particles increased. The sequence is the opposite of that found in ARN site only $250 \mathrm{~km}$ away. 
Table 6. Effective radius $\left(r_{\text {eff }}^{\mathrm{GL}}\right)$ (in $\left.\mu \mathrm{m}\right)$ for the total $(T)$, fine $(f)$ and coarse $(c)$ modes in ARN site and for the coarse mode $(c)$ in GRA site, as calculated from ground-level in-situ particle size distribution observations.

\begin{tabular}{llllll}
\hline \multicolumn{3}{c}{ "El Arenosillo" (ARN-INTA) } & \multicolumn{2}{c}{ Granada (GRA-UGR) } \\
\hline Time (UTC) & $r_{\text {eff }}^{T}$ & $r_{\text {eff }}^{f}$ & $r_{\text {eff }}^{c}$ & Time (UTC) & $r_{\text {eff }}^{c}$ \\
\hline \multicolumn{5}{c}{ 14 March 2008 } \\
09:00 & 0.17 & 0.10 & 1.52 & $00: 00$ & 1.06 \\
$15: 00$ & 0.3 & 0.10 & 1.72 & $15: 00$ & 1.50 \\
$02: 00$ & 0.36 & 0.12 & 1.14 & $02: 00$ & 1.14 \\
$05: 00$ & 0.19 & 0.12 & 1.08 & $07: 00$ & 1.29 \\
$12: 00$ & 0.35 & 0.15 & 1.12 & $16: 00$ & 1.38 \\
\hline
\end{tabular}

VSD $^{\text {AERONET }}$ data associated to the dust occurrence on 14 March, as previously presented in Sect 5.1.1, are only available at 08:25 UTC in ARN (see Fig. 4a) and at 15:25 UTC and 15:39 UTC in GRA site (see Fig. 4b). At these times, in-situ measurements indicate that the dust intrusion was just starting to be observed at ground-level. This fact evidences clearly the differences found between columnar-integrated measurements and the ground-level boundary layer data as a result of the time required for the gravitational settling of the lofted aerosol particles associated to the arrival of Saharan dust over the study area.

In order to analyze the particle size more influential in relation to the aerosol in-situ optical parameters, the effective radius at ground level $\left(r_{\text {eff }}^{\mathrm{GL}}\right)$ has been calculated from the $\mathrm{VSD}^{\mathrm{GL}}$ data. $r_{\mathrm{eff}}^{\mathrm{GL}}$ is defined as the ratio of the thirdto-second moments of the $\mathrm{VSD}^{\mathrm{GL}}$, and the values for the total concentration, the fine mode (size ranges: TV0 and TV1) and the coarse mode (size ranges: TV2 and TV3) are shown in Table 6. During the ARN dust event on the surface, $r_{\text {eff }}^{\mathrm{GL}}$ for the coarse mode decreases, ranging from $1.72 \mu \mathrm{m}$ to $1.08 \mu \mathrm{m}$. However, this continuous decreasing behaviour is not detected in GRA site. Despite an initial $r_{\text {eff }}^{\mathrm{GL}}$ decrease for the coarse mode is observed from 14 March at 22:00 UTC to 15 March at 02:00 UTC, with values ranging from $1.29 \mu \mathrm{m}$ to $1.14 \mu \mathrm{m}$, close to $07: 00 \mathrm{UTC}$ this trend is modified. This change can be explained because of the re-suspension of particulate matter from urban paved roads due to traffic early in the morning, obtaining higher $r_{\text {eff }}^{\mathrm{GL}}$ values for the coarse mode (Lyamani et al., 2008, 2010).

Both $r_{\text {eff }}^{\mathrm{GL}}$ and $r_{\mathrm{eff}}^{\mathrm{AERONET}}$ are analysed for comparison purposes. A strong dust occurrence as observed from the columnar-integrated data seems to have only a light influence on the surface when ground-level in-situ measurements are analysed (i.e., on 14 March at about 09:00 UTC and 16:00 UTC in ARN and GRA sites respectively, see Fig. 4). Hence, AERONET inversion data are about a factor of 5.5 and 1.6 higher than in-situ measurements for the total and fine mode, respectively, of the $\mathrm{VSD}^{\mathrm{GL}}$ in ARN site. This factor (the ratio $r_{\text {eff }}^{\mathrm{AERONET}} / r_{\mathrm{eff}}^{\mathrm{GL}}$ ) is about $1.1 \pm 0.1$ for the $\mathrm{VSD}^{\mathrm{GL}}$ coarse mode in both ARN and GRA sites. These $r_{\text {eff }}^{\mathrm{AERONET}}$ values are higher (see Tables 3 and 6 ) because the concentrations for the TV1 (fine) and TV2 and TV3 (coarse) size ranges of the columnar-integrated VSD ${ }^{\text {AERONET }}$ are higher than those found on the ground level. This ratio $r_{\text {eff }}^{\mathrm{AERONET}} / r_{\text {eff }}^{\mathrm{GL}}$ is also analysed for non-dusty conditions (see Fig. 4). $r_{\mathrm{eff}}^{\mathrm{AERONET}} / r_{\text {eff }}^{\mathrm{GL}}$ values of $1.4 \pm 0.3$ and $1.2 \pm 0.2$ are found for the total concentration and fine mode fraction, respectively, in ARN site. This ratio is about $1.5 \pm 0.1$ for the coarse mode in both sites. In any case, AERONET retrievals still provide larger effective radius than those obtained from ground-level in-situ measurements. However, these results are contrary to those reported by Müller et al. (2010a), where AERONET and airborne in-situ measurements at $3247 \mathrm{~m}$ and $4853 \mathrm{~m}$ were compared under dusty conditions. In that work, the particle effective radius from the AERONET algorithm turned out to be smaller.

Hence, these differences respect to AERONET data are positive or negative, depending on the in-situ measurements platform, either airborne or ground-level, respectively. This apparent discrepancy on the incidence behaviour of the dusty episode, together with the analysis of closest-to-surface backtrajectories (see Sect. 5.3.1), reflect a clear dependence of the VSD and $r_{\text {eff }}$ for dust particles on height. Then, further vertical size-resolved observations are needed for assessment of the impact on surface of the Saharan dust arrival to the Iberian Peninsula.

\section{(b) Aerosol optical properties}

Scattering coefficient at $550 \mathrm{~nm}\left(\mathrm{SC}^{550}\right)$, Ångström exponent (550/700 nm wavelength pair, $\left.\mathrm{AE}_{\mathrm{np}}^{550 / 700}\right)$ and backscatter fraction at $550 \mathrm{~nm}\left(\mathrm{BSC}^{550}\right)$ for surface particles with a diameter lower than $10 \mu \mathrm{m}$ are also examined, as representatives of optical properties, along the overall monitored period. Temporal evolution of these parameters $\mathrm{SC}^{550}$, $\mathrm{AE}_{\mathrm{np}}^{550 / 700}$ and $\mathrm{BSC}^{550}$ (hourly averaged values) in both ARN and GRA stations is shown in Fig. 13a and b, respectively. During RAP episode at ARN station (see Fig. 13a), the $\mathrm{SC}^{550}$ presents a large enhancement, increasing from $30 \mathrm{Mm}^{-1}$ to $123 \mathrm{Mm}^{-1}$, and its maximum value coincides with the peak observed in TV0 and TV1. A mean $\mathrm{AE}_{\mathrm{np}}^{550 / 700}$ value of $1.8 \pm 0.1$ is obtained for this event, indicating a predominance of fine particles. As representative of GRA DP event (see Fig. 13b), the episode occurred on 13 March is selected. $\mathrm{SC}^{550}$ values obtained during this event are similar to those obtained for the RAP episode at ARN station. A mean $\mathrm{AE}_{\mathrm{np}}^{550 / 700}$ value of $1.5 \pm 0.3$ is found, representing a fine particle dominance. Both RAP and DP episodes, differently originated, present similar scattering properties with 

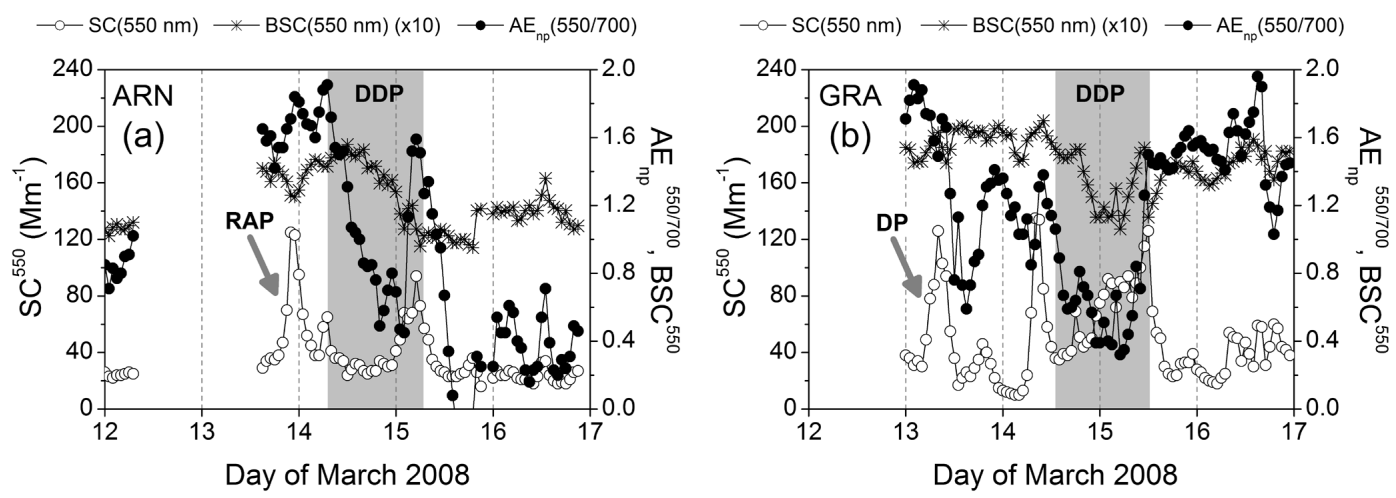

Fig. 13. Temporal evolution of the scattering coefficient at $550 \mathrm{~nm}\left(\mathrm{SC}^{550}\right)$, the Ångström Exponent $\left(\mathrm{AE}_{\mathrm{np}}^{550 / 700}\right)$ and the backscatter fraction at $550 \mathrm{~nm}\left(\mathrm{BSC}^{550}\right)$ for surface particles with a particle diameter lower than $10 \mu \mathrm{m}$ for the overall period of 12-16 March 2008 in both (a) ARN and (b) GRA sites.

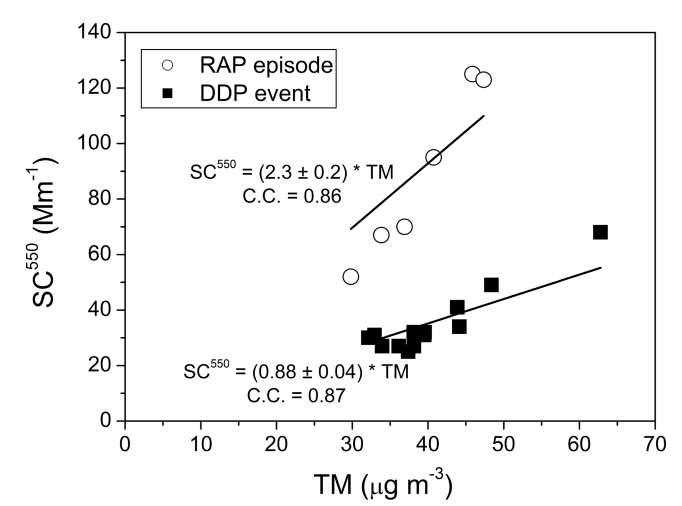

Fig. 14. Relation between $\mathrm{SC}^{550}$ y total mass (TM) concentration (as evaluated from the volume size distribution and assuming a particle density of $2 \mathrm{~g} \mathrm{~cm}^{-3}$ ), during a Regional Anthropogenic Plume (RAP) episode and the Desert Dust Plume (DDP) event over ARN station.

differences in the particle micrometer-size range (see previous analysis of this section).

During the ARN DDP episode hourly-averaged $\mathrm{AE}_{\mathrm{np}}^{550 / 700}$ values decreased from 1.88 to 0.45 . Mean $\mathrm{AE}_{\mathrm{np}}^{550 / 700}$ and $\mathrm{SC}^{550}$ values of $1.1 \pm 0.4$ and $43 \pm 18 \mathrm{Mm}^{-1}$, respectively, were obtained. The highest impact of this DDP episode in ARN site shows an increase of the TV 3 concentration with the lowest $\mathrm{AE}_{\mathrm{np}}^{550 / 700}$ and $\mathrm{BSC}^{550}$ values, indicative of a dominance of those large aerosols over the scattering process (see Figs. 10, 11a and b). A mean $\mathrm{AE}_{\mathrm{np}}^{550 / 700}$ value of $0.7 \pm 0.2$ is found for this intense period, in agreement with previous reported results on dust optical properties (i.e., Kim et al., 2005), and also similar $\mathrm{SC}^{550}$ values for the overall DDP period to those analyzed in White et al. (1994) and Chang et al. (2006). In the case of GRA station, the DDP $\mathrm{AE}_{\mathrm{np}}^{550 / 700}$ decreased from 0.89 to 0.32 , with a mean value of $0.7 \pm 0.3$. A mean $\mathrm{SC}^{550}$ value of $71 \pm 25 \mathrm{Mm}^{-1}$ was found for this dusty period. These results for $\mathrm{AE}_{\mathrm{np}}^{550 / 700}$ and $\mathrm{SC}^{550}$ are similar to those obtained by Kalivitis et al. (2007) and Pereira et al. (2008).

By comparing the results obtained in both Southern Iberian Peninsula stations, $\mathrm{SC}^{550}$ values are around 1.6 times higher in GRA than those obtained in ARN station during the DDP episode, because of the significant contribution from local anthropogenic sources in the urban GRA site. In addition, lower $\mathrm{AE}_{\mathrm{np}}^{550 / 700}$ values found in GRA station are in agreement with the high TV2 and TV3 concentrations observed in GRA site (see Fig. 11). SC ${ }^{550}$ values for both stations during the DDP episode are lower than those found for typical sites with higher local pollution levels, which contribute to high aerosol loadings during the DDP event (Kim et al., 2005; Chang et al., 2006).

In order to evaluate the aerosol effectiveness on solar light radiation, the mass scattering coefficient efficiency at $550 \mathrm{~nm}$ $\left(\mathrm{SC}_{m}^{550}\right)$, defined as the ratio of $\mathrm{SC}^{550}$ to the aerosol total mass concentration (TM) (i.e., Kalivitis et al., 2007), is determined. In this work, TM is calculated by the product of the effective density $\left(2 \mathrm{~g} \mathrm{~cm}^{-3}\right.$ is assumed) and the ground-level volume size distribution $\left(\mathrm{VSD}^{\mathrm{GL}}\right)$. Since $\mathrm{SC}^{550}$ is obtained for particles with sizes lower than $10 \mu \mathrm{m}$ and no TV0 concentration is available in GRA station, the analysis is performed only for ARN station. Lineal regression of $\mathrm{SC}^{550}$ versus TM is shown in Fig. 14 for the RAP event (open circles) and the DDP episode (full squares). In both cases high correlation coefficients (C.C.) of $0.86-0.87$ are obtained, indicating a good relation between optical and microphysical parameters. $\mathrm{SC}_{m}^{550}$ values of $0.88 \pm 0.04 \mathrm{~m}^{2} \mathrm{~g}^{-1}$ and $2.3 \pm 0.2 \mathrm{~m}^{2} \mathrm{~g}^{-1}$ are found for dusty and non-dusty periods, respectively. Therefore, anthropogenic industrial particles are 2.5 times more efficient for solar light scattering than dust particles. These values are in good agreement with others previously reported for the same kind of aerosols (Kim et al., 2005; Chang et al., 2006; Pereira et al., 2008). 


\subsubsection{Dust particle sedimentation}

From previously exposed backtrajectory and size-resolved analysis, it came out that the origin of the DDP episode observed at ground level in both ARN and GRA stations is from Northern Africa. But those air masses arrive at closest-tosurface heights over both stations instead of coming from that observed 3-km height dust plume with a Saharan-Tenerife pathway, as shown by lidar measurements and HYSPLIT backtrajectories (see previous sections). These results can be justified in relation with the suspension time estimated for these dust particles till their deposition on the surface.

By examining the 3-km wind fields provided by the BSC/DREAM dust model (Barcelona Supercomputing Center/Dust REgional Atmospheric Model, http://www.bsc.es/ projects/earthscience/DREAM/, data not shown), the dust plume at these altitudes was travelling with a speed of about $40 \mathrm{~km} \mathrm{~h}^{-1}$, and it took $30 \mathrm{~h}$ to reach the Southern coast of the Iberian Peninsula. On the other hand, particle sedimentation depends on size, density and air viscosity (Hinds, 1999; Osborne and Haywood, 2005). For small particles with sizes approaching the mean free-path of the gas, there is a "slip" of the particle (the relative velocity of the gas at the surface of the particle is cero) and the pressure-dependent Cunningham correction factor has to be included in the Stoke's equation. The differences start to be meaningful above $1 \mu \mathrm{m}$ in diameter (Hinds, 1999; Osborne and Haywood, 2005). Saharan dust $10-\mu \mathrm{m}$ size particles travelling at $3000 \mathrm{~m}$ sediment by $600 \mathrm{~m}_{\text {day }^{-1}}$, while $5-\mu \mathrm{m}$ particle settling is only of $200 \mathrm{~m}$ day $^{-1}$.

In consequence, rather low particle sedimentation is expected to occur before the dust plume reaches the South coast of the Iberian Peninsula. This confirms the surface in-situ results obtained for both ARN and GRA stations, as stated before.

\section{Conclusions}

The relevance of the synergetic use of simultaneous remote sensing and in-situ observations for aerosol research is highlighted in this work. Meteorological information, AERONET data, lidar observations, backtrajectory analysis and surface in-situ measurements have been used for characterization of dust intrusions coming from Saharan region. A medium-range dust plume transported from the Canary Islands to the Iberian Peninsula, located relatively close and far away from the dust sources, respectively, has been exhaustively monitored from 11 to 19 of March 2008. Observations were performed over three Spanish geographically strategic stations within the dust-influenced area along a common dust plume pathway: Santa Cruz de Tenerife Observatory (SCO, AEMET) in the Canary Islands, and the Atmospheric Sounding Station "El Arenosillo" (ARN, INTA) and the Granada Station (GRA, UGR) in the Southwest and Southeast of the
Iberian Peninsula, respectively. A 4-day dust event was detected over SCO station lasting from 13 till 16 March 2008; the same dust air mass was observed over the South of the Iberian Peninsula on 14 March 2008 at both ARN and GRA sites.

The meteorological situation over the area under study favoured the dust plume transport from the Saharan region to the Canary Islands, and then to the Southern Iberian Peninsula. Backtrajectory analysis shows a common Saharan origin of the dust air masses over all the stations at 3-km height. AERONET data have been used to confirm the dust particles loading in those plumes in basis of selected AOD and $\mathrm{AE}$ ranges: daily mean moderate/high AOD values (0.3-0.6) together with low $\mathrm{AE}<0.5$ are found over all three stations for dust intrusion.

Lidar observations have characterized the vertical layering structure of those dust plumes, identifying different aerosol contributions depending on altitude. Dust layer tops are found at $4.5-5.0 \mathrm{~km}$ height in all stations. SCO backscatter profiling displays a multilayered structure through the overall atmosphere up to the top, meanwhile ARN and GRA profiles present mainly a single dust layer of $2.0 \mathrm{~km}$ thick confined between 2.5 and $4.5 \mathrm{~km}$ height and peaking at about $3.2 \mathrm{~km}$. Backtrajectories at these height levels confirm the Saharan origin of the plume moving through the Canary Islands and observed over SCO, before reaching the Iberian Peninsula. In addition, a minor aerosol (continental/anthropogenic) contribution is observed in GRA station below $2.5 \mathrm{~km}$ related to air masses crossing through the Iberian Peninsula before arriving to the station, as also confirmed by backtrajectory analysis. Lidar-retrieved LR values have been estimated for each station, being decisive the selection of a suitable aerosol scenario for data retrieval. Realistic aerosol conditions over SCO are obtained when using the proposed "mixed dust" scenario (MDS) with aerosol-type discrimination. LR values of $24 \mathrm{sr}, 31 \mathrm{sr}$, and $25 \mathrm{sr}$ are found under non-dusty conditions, and $69 \mathrm{sr}, 65 \mathrm{sr}$ and $63 \mathrm{sr}$ for the principal dusty episodes over SCO, ARN and GRA, respectively. The similar values obtained in all three stations provide evidence on the dust plume properties being unchanged in the course of its medium-range transport. These values are in good agreement with those previously reported for dust particles (i.e., Müller et al., 2007; Papayannis et al., 2008). However, LR for dust particles are underestimated if AERONET retrieved data are used, unless a dust more realistic model is used instead in the AERONET inversion algorithm (Müller et al., 2010b).

Moreover, the potential impact on surface of that Saharan dust plume arriving at the Iberian Peninsula has been evaluated by ground-level in-situ measurements for particle deposition assessment. An 8-h delay on dust arrival times at ground level between ARN and GRA sites is found. Differences on particle deposition process are observed in both sites by using the temporal evolution of the total volume (TV) particle concentration for discrete size ranges. Meanwhile 
TV3 $(2.5-10 \mu \mathrm{m})$ size particles are detected $10 \mathrm{~h}$ before the TV2 $(1.0-2.5 \mu \mathrm{m})$ ones in ARN, the particle behaviour over GRA is just opposite. The TV2 particles arrived $9 \mathrm{~h}$ before the larger TV3 ones. These differences can be explained by the particular transport pattern occurred in each station. Backtrajectory analysis confirms that those closestto-surface air masses arriving at both sites from the Northern African continent, are coming to GRA from lower heights than those reaching ARN station. Therefore, particles over ARN would be the result of a gravitational deposition process, while those in GRA would be mostly influenced by their horizontal movement. The first behaviour is related to the faster gravitational deposition (vertical velocity) for larger particles than smaller ones, and the second one is associated to a slower horizontal movement for the large particles.

Despite the scarce AERONET volume size distributions $\left(\mathrm{VSD}^{\mathrm{AERONET}}\right.$ ) available during the dusty period in both ARN and GRA sites, the retrieved effective radius was compared with those calculated from the most coincident in time ground-level in-situ measurements. The ratio $r_{\mathrm{eff}}^{\mathrm{AERONET}} / r_{\mathrm{eff}}^{\mathrm{GL}}$ presents values higher than 1 , in particular, 5.5 and 1.6 for the total concentration and the fine mode fraction of the VSD, respectively, as obtained in ARN site, and 1.1 for the coarse mode in both ARN and GRA sites. These results $\left(r_{\text {eff }}^{\text {AERONET }}\right.$ $>r_{\text {eff }}^{\mathrm{GL}}$ ) as compared to those opposite obtained by Müller et al. (2010a), where AERONET and airborne in-situ measurements were performed, reveal a clear dependence of the dust particles properties on height, as reflected by the different insitu measurements platform (either ground-level or airborne) used. Therefore, further vertical size-resolved observations are needed for a more complete understanding of the dust particles properties, and then for assessment of the impact on surface of the Saharan dust arrival to the Iberian Peninsula.

A more detailed analysis of the backtrajectories ending at several heights over each station reveals that those closestto-surface air masses are coming directly from the Northern African continent, whereas those ending at 3-km carrying the dust plume are coming from the considered Sahara-TenerifeIberian Peninsula pathway. Sedimentation analysis based on particle size, density and air viscosity computation confirms that previous statement. The deposition process starts to be meaningful for particles above $1 \mu \mathrm{m}$ in diameter, but even for dust $10-\mu \mathrm{m}$ size particles, the sedimentation would be by $600 \mathrm{~m} \mathrm{day}^{-1}$, i.e., dust plume particles travelling at 3$\mathrm{km}$ height take 5 days to reach the surface. In consequence, rather low particle sedimentation is expected to occur directly from the dust $3-\mathrm{km}$ height plume once reached the Southern Iberian Peninsula. Therefore, dust particles registered at ground level are not related to deposition processes for particles of that monitored dust plume, being thus its potential impact on surface rather low. However, dust incidence exists in relation to direct surface air masses arriving from the Northern Africa continent, as stated before. The dust event as monitored on the ground level over Southern Iberian Peninsula presents a higher incidence in the Southeastern region respect to the Southwestern area by comparison of both TV 2 and TV 3 concentrations registered over both GRA and ARN stations. In addition, both optical parameters $\mathrm{SC}^{550}$ and $\mathrm{AE}_{\mathrm{np}}^{550 / 700}$ obtained in the urban GRA site are 1.6 higher and 1.7 lower, respectively, than those found in a rural/coastal environment like ARN station. Furthermore, aerosol effectiveness on solar light interaction is evaluated in ARN station on the basis of the mass scattering coefficient $\mathrm{SC}_{\mathrm{m}}^{550}$, resulting in a value close to $0.9 \mathrm{~m}^{2} \mathrm{~g}^{-1}$ for dust and $2.3 \mathrm{~m}^{2} \mathrm{~g}^{-1}$ for regional anthropogenic industrial aerosols. This indicates the former particles are 2.5 times more efficient for solar light scattering than dust particles.

In summary, synergetic, i.e. multi-instrumented and simultaneous, use of: (1) height-resolved dust structure obtained by lidar measurements; (2) optical/microphysical properties derived from AERONET columnar-integrated data; (3) both horizontal and vertical backtrajectory analysis of air masses; and (4) meteorological information, in different aerosol stations, represents an important advantage for the characterization of dust properties in the course of their transport from desert source regions as far as their surface deposition. In addition, ground-level in-situ measurements together with closest-to-surface backtrajectory analysis provide a relevant tool to discriminate different deposition processes and highlight the aerosol-dependent relation between microphysical and optical properties. Moreover, height-resolved measurements are more and more required for aerosol research to understand the particular trends in the data as obtained from different technologies and measurements platforms. In particular, together with the methodology used in this work, the use of airborne aerosol instrumentation and the development of new lidar inversion algorithms can play a relevant role in this understanding. In this sense, further aerosol research campaigns focused on aerosol microphysical properties retrieval are going on, involving both aerosol airborne and lidar instrumentations.

In particular, this work can be presented as a first step to organize a Spanish Warning System for Saharan dust intrusions that frequently affect the Canary Islands and the Iberian Peninsula. Obtained results can be used as a reference for dust monitoring over other dust-influenced regions.

Acknowledgements. This work has been supported by the Spanish Ministry for Science and Innovation (MICINN) under the Complementary Actions CGL2008-01330-E (2009) in the frame of the Spanish and Portuguese Aerosol LIdar NETwork (SPALINET), and CGL2010-10012-E (Evaluation of lidar observations in the frame of CIEMAT/EARLINET intercomparison by airborne in-situ measurements of trace gases and aerosols, MISPA-LIDAR, 2010); projects CGL2008-05939-C03-03/CLI, CGL2007-66477-C02-01, CSD2007-00067 and CGL2010-18782 of the Spanish Ministry of Education; projects P08-RNM-3568 and P10-RNM-6299 of the Autonomous Government of Andalusia; and the EARLINET-ASOS project (EU Coordination Action, contract no. 025991 (RICA)). 
Authors would like to express their gratitude to the NOAA Air Resources Laboratory (ARL) for the HYSPLIT backtrajectories, the NOAA/ESRL Physical Sciences Division in Boulder Colorado for the meteorological synoptic charts, the Barcelona Supercomputing Centre (BSC) for the DREAM forecast and EUSAAR Project for providing technical support for in-situ equipment in ARN station. JLG-R thanks the Spanish Ministry of Education and the Portuguese Fundação para a Ciência e a Tecnologia for supporting under grants EX2009-0700 and SFRH/BPD/63090/2009, respectively. Both the anonymous reviewers are gratefully acknowledged for their valuable and useful comments and suggestions.

Edited by: A. Petzold

\section{References}

Alados-Arboledas, L., Lyamani, H., and Olmo, F. J.: Aerosol size properties at Armilla, Granada (Spain), Quarterly Journal of the Royal Meteorological Society, 129, 1395-1413, 2003.

Alados-Arboledas, L., Alcántara, A., Olmo, F. J., Martínez-Lozano, J. A., Estellés, V., Cachorro, V., Silva, A. M., Horvath, H., Gangl, M., Díaz, A., Pujadas, M., Lorente, J., Labajo, A., Sorribas, M., and Pavese, G.: Aerosol columnar properties retrieved from CIMEL radiometers during VELETA 2002, Atmos. Environ., 42, 2654-2667, 2008.

Anderson, T. L. and Ogren, J. A.: Optimal determination of aerosol radiative properties using the TSI 3563 nephelometer, Aerosol Sci. Tech., 29, 57-69, 1998.

Andreade, M. O.: Climatic effects of changing atmospheric aerosol levels, edited by: A. Henserson-Sellers, in: World Survey of Climatology, 16, Future Climates of the World, Elsevier, Amsterdam, The Netherlands, 341-392, 1995.

Ångström, A.: The parameters of atmospheric turbidity, Tellus, 16, 64-75, 1964.

Ansmann, A.: Ground-truth aerosol lidar observations: can the Klett solutions obtained from ground and space be equal for the same aerosol case?, Appl. Opt., 45(14), 3367-3371, 2006.

Ansmann, A., Bösenberg, J., Chaikovsky, A., Comeron, A., Eckhardt, S., Eixmann, R., Freudenthaler, V., Ginoux, P., Komguem, L., Linne, H., Lopez Marquez, M. A., Matthias, V., Mattis, I., Mitev, V., Müller, D., Music, S., Nickovic, S., Pelon, J., Sauvage, L., Sobolewsky, P., Srivastava, M. K., Stohl, A., Torres, O., Vaughan, G., Wandinger, U., and Wiegner, M.: Long-range transport of Saharan dust to northern Europe: The 11-16 October 2001 outbreak observed with EARLINET, J. Geophys. Res., 108 (D24), 4783, doi:10.1029/2003JD003757, 2003.

Balis, D., Papayannis, A., Galani, E., Marenco, F., Santacesaria, V., Hamonou, E., Chazette, P., Ziomas, I., and Zerefos, C.: Tropospheric LIDAR aerosol measurements and sun photometric observations at Thessaloniki, Greece, Atmos. Environ., 34 (6), 925-932, 2000.

Balis, D. S., Zerefos, C. S., Kourtidis, K., Bais, A. F., Hofzumahaus, A., Kraus, A., Schmitt, R., Blumthaler, M., and Gobbi, G. P.: Measurements and modeling of the photolysis rates during the photochemical activity and ultraviolet radiation (PAUR) II campaign, J. Geophys. Res., 107 (D18), 8138, doi:10.1029/2000JD000136, 2002.

Balis, D., Amiridis, V., Nickovic, S., Papayannis, A., and Zerefos, C.: Optical properties of Saharan dust layers as detected by a
Raman lidar at Thessaloniki, Greece, Geophys. Res. Lett., 31, L13104, doi:10.1029/2004GL019881, 2004.

Basart, S., Pérez, C., Cuevas, E., Baldasano, J. M., and Gobbi, G. P.: Aerosol characterization in Northern Africa, Northeastern Atlantic, Mediterranean Basin and Middle East from direct-sun AERONET observations. Atmos. Chem. Phys., 9, 8265-8282, doi:10.5194/acp-9-8265-2009, 2009.

Bonasoni, P., Cristofanelli, P., Calzolari, F., Bonafè, U., Evangelisti, F., Stohl, A., Zauli Sajani, S., van Dingenen, R., Colombo, T., and Balkanski, Y.: Aerosol-ozone correlations during dust transport episodes, Atmos. Chem. Phys., 4, 1201-1215, doi:10.5194/acp-4-1201-2004, 2004.

Cachorro, V. E., Toledano, C., Prats, N., Sorribas, M., Mogo, S., Berjón, A., Torres, B., Rodrigo, R., De la Rosa, J., and De Frutos, A. M.: The stronger desert dust intrusions mixed with smoke over the Iberian Peninsula registered with Sun photometry, J. Geophys. Res., 113, D14S04, doi:10.1029/2007JD009582, 2008.

Campbell, J. R., Hlavka, D. L., Welton, E. J., Flynn, C. J., Turner, D. D., Spinhirne, J. D., Stanley Scott III, V., and Hwang, I. H.: Full-time, eye-safe cloud and aerosol Lidar observation at atmospheric radiation measurement program sites: Instruments and data processing, J. Atmos. Ocean. Tech., 19, 431-442, 2002.

Cattrall, C., Reagan, J., Thome, K., and Dubovik, O.: Variability of aerosol and spectral lidar and backscatter and extinction ratios of key aerosol types derived from selected Aerosol Robotic Network locations, J. Geophys. Res., 110, D10S11, doi:10.1029/2004JD005124, 2005.

Chang, S.-Y., Fang, G.-C., Chou, C. C.-K., and Chen, W.-N.: Chemical compositions and radiative properties of dust and anthropogenic air masses study in Taipei Basin, Taiwan, during spring of 2004, Atmos. Environ., 40, 7796-7809, 2006.

Córdoba-Jabonero, C., Gil, M., Yela, M., Maturilli, M., and Neuber, R.: Lidar observations of Arctic aerosols and PSC detection in winter 2007 at the Koldewey station (Ny-Alesund, Norway). The second AWIPEV scientific workshop: French - German Polar Science on Spitsbergen during IPY, Bremen (Germany), 8-10 October, 2008.

Córdoba-Jabonero, C., Gil, M., Yela, M., Maturilli, M., and Neuber, R.: Polar Stratospheric Cloud observations in the 2006/07 Arctic winter by using an improved Micro Pulse Lidar. J. Atmos. Ocean. Technol., 26, 2136-2148, 2009.

Córdoba-Jabonero, C., Hernández, Y., Gil, M., and Cuevas, E.: Aerosol scenario effect in elastic lidar data inversion for lidar ratio estimation: a case study over a coastal dust-influenced area. IV Spanish Meeting on Aerosol Science and Technology (RECTA 2010), Granada (Spain), edited by: Alados Arboledas, L., Olmo Reyes, F. J., Guerrero Rascado, J. L., and Anton Martinez, M., Universidad de Granada, Granada, Spain, Extended Abstract, G3-1:-G3-5, ISBN: 978-84-693-4839-0, 2010.

Draxler, R. R. and Hess, G. D.: An overview of the HYSPLIT 4 modeling system for trajectories, dispersion, and deposition, Australian Meteorology Magazine, 47, 295-308, 1998.

Draxler, R. R., Stunder, B., Rolph, G., and Taylor, A.: Hysplit 4 User's Guide, NOAA Air Resources Laboratory, Silver Spring, MD, USA, 2009.

Dubovik, O. and King, M. D.: A flexible inversion algorithm for retrieval of aerosol optical properties from sun and sky radiance measurements. J. Geophys. Res., 105, 20673-20696, 2000. 
Dubovik, O., Holben, B. N., Lapyonok, T., Sinyuk, A., Mishchenko, M. I., Yang, P., and Slutsker, I.: Non-spherical aerosol retrieval method employing light scattering by spheroids. Geophys. Res. Lett., 29(10), 1415, doi:10.1029/2001GL014506, 2002a.

Dubovik, O., Holben, B., Eck, T. F., Smirnov, A., Kaufman, Y. J., King, M. D., Tanré, D., and Slutsker, I: Variability of absorption and optical properties of key aerosol types observed in worldwide locations, J. Atmos. Sci., 59, 590-608, 2002b.

Dubovik, O., Sinyuk, A., Lapyonok, T., Holben, B. N., Mishchenko, M., Yang, P., Eck, T. F., Volten, H., Muñoz, O., Veihelmann, B., van der Zande, W. J., Leon, J.-F., Sorokin, M., and Slutsker, I.: The application of spheroid models to account for aerosol particle nonsphericity in remote sensing of desert dust. J. Geophys. Res., 111, D11208, doi:10.1029/2005GL06619, 2006.

Dulac, F., Buat-Ménard, P., Sutton, D., Tanré, D., Bergametti, G., and Debois, M.: Assessment of the African airborne dust mass over the Western Mediterranean Sea using Meteosat data, J. Geophys. Res., 97, 2489-2506, doi:10.1029/91JD02427, 1992.

Dulac, F., Attie, J-L., Bergametti, G., Mallet, M., Sciare, J., Tanre, D., Borbon, A., Coppola, L., Chazette, P., Desboeufs, K., Durand, P., Flamant, C., Gheusi, F., Gomes, L., Guieu, C., Lambert, D., Liousse, C., Losno, R., Marchand, N., Mari, C., Notton, G., Peuch, V.-H., Ravetta, F., Ricaud, P., Savelli, J.-L., Seigneur, C., Turquety, S., and Verdier, N.: The Chemistry-Aerosol Mediterranean Experiment (ChArMEx), $1^{\text {st }}$ International Workshop, Toulouse, France, 29 June-1 July, 2009, Météo-France, Toulouse, France.

Escudero, M., Querol, X., Pey, J., Alastuey, A., Pérez, N., Ferreira, F., Alonso, S., Rodríguez, S., and Cuevas, E.: A methodology for the quantification of the net African dust load in air quality monitoring Networks, Atmos. Environ., 41(26), 5516-5524, 2007.

Fernald, F. G., Herman, B. M., and Reagan, J. A.: Determination of aerosol height distribution by lidar, J. Appl. Meteorol., 11, 482489, 1972 .

Fernald, F. G.: Analysis of atmospheric lidar observations: some comments, Appl. Optics, 23, 652-653, 1984.

Fernández-León, M., Sorribas, M., Alados-Arboledas, L., de la Morena B: Aerosol particle microphysical properties during the 2009 summer in El Arenosillo. IV Spanish Meeting on Aerosol Science and Technology (RECTA 2010), Granada (Spain), edited by: Alados Arboledas, L., Olmo Reyes, F. J., Guerrero Rascado, J. L., and Anton Martinez, M., Universidad de Granada, Granada, Spain, Extended Abstract, A3-1:-A3-6, ISBN: 978-84693-4839-0, 2010.

González-Castanedo, Y., De la Rosa, J. D., Sánchez de la Campa, A., Alastuey, A., Querol, X., Cachorro, V., Sorribas, M., and Bolívar, J. P.: Levels, chemicals composition and mass contribution of particulate matter in a rural monitoring station, Proceedings of the $6^{a}$ Asamblea Hispano-Portuguesa de Geodesia y Geofísica, Tomar, Portugal, 11-14 February, 2008, Universidad de Tomar, Portugal.

Guerrero-Rascado, J. L., Ruíz, B., and Alados-Arboledas, L.: Multi-spectral Lidar characterization of the vertical structure of Saharan dust aerosol over southern Spain. Atmos. Environ., 42, 2668-2681, 2008.

Guerrero-Rascado, J. L., Olmo, F. J., Avilés-Rodríguez, I., NavasGuzmán, F., Pérez-Ramírez, D., Lyamani, H., and AladosArboledas, L.: Extreme Saharan dust event over the southern
Iberian Peninsula in September 2007: Active and passive remote sensing from surface and satellite, Atmos. Chem. Phys., 9, 84538469, doi:10.5194/acp-9-8453-2009, 2009.

Hamonou, E., Chazette, P., Balis, D., and Papayannis, A.: Characterization of the vertical structure of Saharan dust export to the Mediterranean basin, J. Geophys. Res., 104 (D18), $22257-$ $22270,1999$.

Holm, R. L., Caldow, R., Hairston, P. P., Quant, F. R., and Sem, G. J.: An enhanced time-of-flight spectrometer that measures aerodynamic size plus light-scattering intensity, J. Aerosol Sci., 28, S1, S11-S12, 1997.

IPCC 2007: Climate Change and Water. Technical Paper of the Intergovernmental Panel on Climate Change, edited by: Bates, B C., Kundzewicz, Z. W., Wu, S., and Palutikof, J. P., IPCC Secretariat, Geneva, 210 pp., 2008.

Kalivitis, N., Gerasopoulos, E., Vrekoussis, M., Kouvarakis, G., Kubilay, N., Hatzianastassiou, N., Vardavas, I., and Mihalopoulos, N.: Dust transport over the eastern Mediterranean derived from Total Ozone Mapping Spectrometer, Aerosol Robotic Network, and surface measurements, J. Geophys. Res., 112, D03202, doi:10.1029/2006JD007510, 2007.

Kalnay, E., Kanamitsu, M., Kistler, R., Collins, W., Deaven, D., Gandin, L., Iredell, M., Saha, S., White, G., Woollen, J., Zhu, Y., Leetmaa, A., Reynolds, R., Chelliah, M., Ebisuzaki, W., Higgins, W., Janowiak, J., Mo, K.C., Ropelewski, C., Wang, J., Jenne, R., and Joseph, D.: The NCEP/NCAR reanalysis 40-year project, B. Am. Meteorol. Soc., 77, 437-471, 1996.

Khlystov, A., Stanier, C., Pandis, S. N: An algorithm for combining electrical mobility and aerodynamic size distributions data when measuring ambient aerosol. Aerosol Sci. Tech., 38 (S1), 229238, 2004.

Kim, S.-W., Yoon, S.-C, Jefferson, A., Ogren, J. A., Dutton, E. G., Won, J.-G., Ghim, Y. S., Lee, B.-I., and Han, J.-S.: Aerosol optical, chemical and physical properties at Gosan, Korea during Asian dust and pollution episodes in 2001, Atmos. Environ., 39, 39-50, 2005.

Klett, J. D.: Stable analytic inversion solution for processing lidar returns, Appl. Optics, 20, 211-220, 1981.

Klett, J. D.: Lidar inversion with variable backscatter/extinction ratios, Appl. Optics, 24, 1638-1643, 1985.

Knutson, E. O., and Whitby, K. T.: Aerosol classification by Electric Mobility: apparatus, theory and applicantions, J. Aerosol Sci., 6, 443-451, 1975.

Landulfo, E., Papayannis, A., Artaxo, P., Castanho, A. D. A., de Freitas, A. Z., Souza, R. F., Vieira Junior, N. D., Jorge, M. P., Sanchez-Coyllo, O. R., and Moreira, D. S.: Synergetic measurements of aerosols over Sao Paulo, Brazil using LIDAR, sunphotometer and satellite data during the dry season, Atmos. Chem. Phys., 3, 1523-1539, doi:10.5194/acp-3-1523-2003, 2003.

Liu, Z., Sugimoto, N., and Murayama, T.: Extinction-to-backscatter ratio of Asian dust observed by high-spectral-resolution lidar and raman lidar, Appl. Opt., 41(15), 2760-2767, 2002.

Liu, Z., Omar, A. H., Hu, Y., Vaughan, M. A., and Winker, D. M.: CALIOP Algorithm Theoretical Basis Document. Part 3: Scene Classification Algorithms. CALIPSO report, PC-SCI-202 Part 3, Release 1.0, 2005.

Lyamani, H., Olmo, F. J., and Alados-Arboledas, L.: Long-term changes in aerosol radiative properties at Armilla (Spain), Atmos. Environ., 38, 5935-5943, 2004. 
Lyamani, H., Olmo, F. J., and Alados-Arboledas, L.: Saharan dust outbreak over southeastern Spain as detected by sun photometer, Atmos. Environ., 39, 7276-7284, 2005.

Lyamani, H., Olmo, F. J., Alcantara, A., and Alados-Arboledas, L.: Atmospheric aerosols during the 2003 heat wave in southeastern Spain I: Spectral optical depth, Atmos. Environ., 40, 6453-6464, 2006a.

Lyamani, H., Olmo, F. J., Alcántara, A., and Alados-Arboledas, L.: Atmospheric aerosols during the 2003 heat wave in southeastern Spain II: Microphysical columnar properties and radiative forcing, Atmos. Environ., 40, 6465-6476, $2006 \mathrm{~b}$.

Lyamani, H., Olmo, F. J., and Alados-Arboledas, L.: Light scattering and absorption properties of aerosol particles in the urban environment of Granada, Spain, Atmos. Environ., 42, 2630-2642, 2008.

Lyamani, H., Olmo, F. J., and Alados-Arboledas, L.: Physical and optical properties of aerosols over an urban location in Spain: seasonal and diurnal variability, Atmos. Chem. Phys., 10, 239254, doi:10.5194/acp-10-239-2010, 2010.

Mamouri, R. E., Amiridis, V., Papayannis, A., Giannakaki, E., Tsaknakis, G., and Balis, D. S.: Validation of CALIPSO spaceborne-derived attenuated backscatter coefficient profiles using a ground-based lidar in Athens, Greece, Atmos. Meas. Tech., 2, 513-522, doi:10.5194/amt-2-513-2009, 2009.

Matthias, V., Bösenberg, J., Freudenthaler, V., Amodeo, A., Balis, D., Chaikovsky, A., Chourdakis, G., Comerón, A., Delaval, A., De Tomasi, F., Eximann, R., Hågård, A., Komguem, L., Kreipl, S., Matthey, R., Mattis, I., Rizi, V., Rodríguez, J. A., Simeonov, V., and Wang, X.: Aerosol lidar intercomparison in the framework of the EARLINET project-Part 1: Instruments. Appl. Opt., 43, 4, 961-976, 2004.

Mogo, S., Cachorro, V. E., Sorribas, M., De Frutos, A., and Fernández, R.: Measurements of continuous spectra of atmospheric absorption coefficients from UV to NIR via optical method, Geophys. Res. Lett., 32, L13811, doi:10.1029/2005GL022938, 2005.

Mona, L., Amodeo, A., Pandolfi, M., and Pappalardo, G.: Saharan dust intrusions in the Mediterranean area: Three years of Raman lidar measurements, J. Geophys. Res., 111, D16203, doi:10.1029/2005JD006569, 2006.

Moulin, C., Lambert, C. E., Dayan, U., Masson, V., Ramonet, M., Bousquet, P., Legrand, M., Balkanski, Y. J., Guelle, W., Marticorena, B., Bergametti, G., and Dulac, F.: Satellite climatology of African dust transport in the Mediterranean atmosphere, J. Geophys. Res., 103, 13137-13144, doi:10.1029/98JD00171, 1998.

Müller, D., Mattis, I., Wandinger, U., Althausen, D., Ansmann, A., Dubovik, O., Eckhardt, S., and Stohl, A.: Saharan dust over a Central European EARLINET-AERONET site: Combined observations with Raman lidar and Sun photometer, J. Geophys. Res., 108, 4345, doi:10.1029/2002JD002918, 2003.

Müller, D., Ansmann, A., Mattis, I., Tesche, M., Wandinger, U., Althausen, D., and Pisani, G.: Aerosol-type-dependent lidar ratios observed with Raman lidar, J. Geophys. Res., 112, D16202, doi:10.1029/2006JD008292, 2007.

Müller, D., Heinold, B., Tesche, M., Tegen, I., Althausen, D., Alados-Arboledas, L., Amiridis, V., Amodeo, A., Ansmann, A., Balis, D., Comeron, A., D'amico, G., Gerasopoulos, E., Guerrero-Rascado, J.-L., Freudenthaler, V., Giannakaki, E.,
Heese, B., Iarlori, M., Knippertz, P., Mamouri, R. E., Mona, L., Papayannis, A., Pappalardo, G., Perrone, R.-M., Pisani, G., Rizi, V., Sicard, M., Spinelli, N., Tafuro, A., and Wiegner, M.: EARLINET observations of the 14-22 May long-range dust transport event during SAMUM 2006: Validation of results from dust transport modeling, Tellus, 61B, 325-339, 2009.

Müller, D., Weinzierl, B., Petzold, A., Kandler, K., Ansmann, A., Müller, T., Tesche, M., Freudenthaler, V., Esselborn, M., Heese, B., Althausen, D., Schladitz, A., Otto, S., and Knippertz, P.: Mineral dust observed with AERONET Sun photometer, Raman lidar, and in situ instruments during SAMUM 2006: Shapeindependent particle properties, J. Geophys. Res., 115, D07202, doi:10.1029/2009JD012520, 2010a.

Müller, D., Ansmann, A., Freudenthaler, V., Kandler, K., Toledano, C., Hiebsch, A., Gasteiger, J., Esselborn, M., Tesche, M., Heese, B., Althausen, D., Weinzierl, B., Petzold, A., and von Hoyningen-Huene, W.: Mineral dust observed with AERONET sun photometer, Raman Lidar, and in-situ instruments during SAMUM 2006: Shape-dependent particle properties, J. Geophys. Res., 115, D11207, doi:10.1029/2009JD012523, $2010 \mathrm{~b}$.

Navas-Guzmán, F., Guerrero-Rascado, J. L., and AladosArboledas, L.: Retrieval of the lidar overlap function using Raman signals, Opt. Pura Apl., 44(1), 71-75, 2011.

Noh, Y. M., Kim, Y. J., and Müller, D.: Seasonal characteristic of lidar ratios measured with a Raman lidar at Gwangju, Korea in spring and autumn. Atmos. Environ., 42, 2208-2224, 2008.

Omar, A. H., Winker, D. M., Kittaka, C., Vaughan, M. A., Liu, Z., Hu, Y., Trepte, C. R., Rogers, R. R., Ferrare, R. A., Lee, K.-P., Kuehn, R. E., and Hostetler, C. A.: The CALIPSO automated aerosol classification and lidar ratio selection algorithm, J. Atmos. Ocean. Techn., 26(10), 1994-2014, 2009.

Papayannis, A., Balis, D., Amiridis, V., Chourdakis, G., Tsaknakis, G., and co-authors: Measurements of Saharan dust aerosols over the Eastern Mediterranean using elastic backscatter-Raman lidar, spectrophotometric and satellite observations in the frame of the EARLINET project, Atmos. Chem. Phys., 5, 2065-2079, doi:10.5194/acp-5-2065-2005, 2005.

Papayannis, A., Amiridis, V., Mona, L., Tsaknakis, G., Balis, D., Bösenberg, J., Chaikovski, A., De Tomasi, F., Grigorov, I., Mattis, I., Mitev, V., Müller, D., Nickovic, S., Perez, C., Pietruczuk, A., Pisani, G., Ravetta, F., Rizi, V., Sicard, M., Trickl, T., Wiegner, M., Gerding, M., Mamouri, R. E., D’Amico, G., and Pappalardo, G., Systematic lidar observations of Saharan dust over Europe in the frame of EARLINET (2000-2002), J. Geophys. Res., 113, D10204, doi:10.1029/2007JD009028, 2008.

Pappalardo, G., Wandinger, U., Mona, L., Hiebsch, A., Mattis, I., Amodeo, A., Ansmann, A., Seifert, P., Linné, H., Apituley, A., Alados-Arboledas, L., Balis, D., Chaikovsky, A., D’Amico, G., De Tomasi, F., Freudenthaler, V., Giannakaki, E., Giunta, A., Grigorov, I., Iarlori, M., Madonna, F., Mamouri, R.-E., Nasti, L., Papayannis, A., Pietruczuk, A., Pujadas, M., Rizi, V., Rocadenbosch, F., Russo, F., Schnell, F., Spinelli, N., Wang, X., and Wiegner, M.: EARLINET correlative measurements for CALIPSO: First intercomparison results, J. Geophys. Res., 115, D00H19, doi:10.1029/2009JD012147, 2010.

Pereira, S., Wagner, F., and Silva, A. M.: Scattering properties and mass concentration of local and long-range transported aerosols over the South Western Iberia Peninsula, Atmos. Environ., 42, 7623-7631, 2008. 
Pérez, C., Nickovic, S., Baldasano, J. M., Sicard, M., Rocadenbosch, F., and Cachorro, V. E.: A long Saharan dust event over the western Mediterranean: Lidar, Sun photometer observations, and regional dust modeling, J. Geophys. Res., 111, D15214, doi:10.1029/2005JD006579, 2006.

Prats, N., Cachorro, V. E., Sorribas, M., Mogo, S., Berjón, A., Toledano, C., de Frutos, A., de la Rosa, J., Laulainen, N., and de la Morena, B.: Columnar aerosol optical properties during "El Arenosillo 2004 summer campaign", Atmos. Environ., 42, 2643-2653, doi:10.1016/j.atmosenv.2007.07.041, 2008.

Prospero, J. M.: Long-range transport of mineral dust in the global atmosphere: Impact of African dust on the environment of the southeastern United States, Proc. Natl. Acad. Sci. USA, 96, 3396-3403, 1999.

Prospero, J.M., Ginoux, P., Torres, O., Nicholson, S., and Gill, T.: Environmental characterization of global sources of atmospheric soil dust identified with the NIMBUS7 Total Ozone Mapping Spectrometer (TOMS) absorbing aerosol product, Rev. Geophys., 40(1), 1002, doi:10.1029/2000RG000095, 2002.

Querol X., Alastuey, A., Moreno, T., Viana, M. M., Castillo, S., Pey, J., Rodríguez, S., Artinano, B., Salvador, P., Sánchez, M., Dos Santos, S. G., Garraleta, M. D . H., Fernández-Patier, R., Moreno-Grau, S., Negral, L., Minguillon, M. C., Monfort, E., Sanz, M. J., Palomo-Marín, R., Pinilla-Gil, E., Cuevas, E., de la Rosa, J., and de la Campa, A. S.: Spatial and temporal variations in airborne particulate matter $\left(\mathrm{PM}_{10}\right.$ and $\left.\mathrm{PM}_{2.5}\right)$ across Spain 1999-2005, Atmos. Environ., 42, 3964-3979, 2008.

Sasano, Y. and Nakane, H.: Significance of the extinction/backscatter ratio and the boundary value term in the solution for the two-component lidar equation, Appl. Optics, 23, 11-13, 1984.

Sasano, Y., Browell, E. V., and Ismail, S.: Error caused by using a constant extinction/backscattering Ratio in Lidar solution, Appl. Optics, 24, 3929-3932, 1985.

Sicard M., Molero, F., Guerrero-Rascado, J. L., Pedrós, R., Expósito, F. J., Córdoba-Jabonero, C., Bolarín, J. M., Comerón, A., Rocadenbosch, F., Pujadas, M., Alados-Arboledas, L., Martínez-Lozano, J. A., Díaz, J. P., Gil, M., Requena, A., NavasGuzmán, F., and Moreno, J.M.: Aerosol lidar intercomparison in the framework of SPALINET - the SPAnish LIdar NETwork: methodology and results, IEEE T. Geosci. Remote Sens., 47 (10), 3547-3559, 2009.

Sicard, M., Rocadenbosch, F., Reba, M. N. M., Comerón, A., Tomás, S., García-Vízcaino, D., Batet, O., Barrios, R., Kumar, D., and Baldasano, J. M.: Seasonal variability of aerosol optical properties observed by means of a Raman lidar at an EARLINET site over Northeastern Spain, Atmos. Chem. Phys., 11, 175-190, doi:10.5194/acp-11-175-2011, 2011.

Sioutas, C., Abt, E., Wolfson, J. M., and Koutrakis, P.: Evaluation of the measurement performance of the Scanning Mobility Particle Sizer and Aerodynamic Particle Sizer, Aerosol Sci. Tech., 30, 84-92, 1999.

Sorribas, M.: Medida y Caracterización del Aerosol Atmosférico en un Ambiente Rural y Costero del Suroeste de Europa. La distribución Numérica de Tamaños en el Rango Sub-micrométrico (Measurements and characterization of atmospheric aerosol in a rural and coastal environment. Sub-micrometer particle number size distribution in Southwestern Europe), PhD. Dissertation, University of Valladolid, Valladolid, Spain, 350 pp., available on- line at: http://sites.google.com/site/marsorribas/, 2008.

Stohl., A.: Computation, accuracy and applications of trajectories A review and bibliography, Atmos. Environ., 32, 947-966, 1998.

Tesche, M., Ansmann, A., Müller, D., Althausen, D., Mattis, I., Heese, B., Freudenthaler, V., Wiegner, M., Esselborn, M., Pisani, G., and Knippertz, P.: Vertical profiling of Saharan dust with Raman lidars and airborne HSRL in southern Morocco during SAMUM, Tellus 61B, 144-164, 2009.

Titos-Vela, G., Foyo-Moreno, I., Lyamani, H. Olmo, F. J., and Alados-Arboledas, L: Estimating absorption and scattering efficiencies for $\mathrm{PM}_{10}$ particles at an urban site. IV Spanish Meeting on Aerosol Science and Technology (RECTA 2010), Granada (Spain), L. Alados Arboledas, F.J. Olmo Reyes, J. L. Guerrero Rascado and M. Antón Martínez (Eds.), Universidad de Granada, Granada, Spain, Extended Abstract, A11-1:-A11-6, ISBN: 97884-693-4839-0, 2010.

Toledano, C., Cachorro, V. E., de Frutos, A. M., Sorribas, M., Prats, N., and de la Morena, B. A.: Inventory of African desert dust events over the southwestern Iberian Peninsula in 2000-2005 with an AERONET Cimel Sun photometer, J. Geophys. Res., 112, D21201, doi:10.1029/2006JD008307, 2007a.

Toledano, C., Cachorro, V. E., Berjón, A., De Frutos, A. M., Sorribas, M., De la Morena, B. A., and Goloub, P.: Aerosol optical depth and Angström exponent climatology at El Arenosillo AERONET site (Huelva, Spain), Q. J. Roy. Meteorol. Soc., 133, 795-807, 2007b.

Toledano, C., Cachorro, V. E., De Frutos, A. M., Torres, B., Berjón, A., Sorribas, M., and Stone, R. S.: Airmass classification and analysis of aerosol types at El Arenosillo (Spain), J. Appl. Meteorol. Clim., 48(5), 962-981, 2009.

Tomasi, F., Blanco, A., and Perrone, M. R.: Raman Lidar monitoring of extinction and backscattering of African dust layers and dust characterization, Appl. Opt., 42, 1699-1709, 2003.

Voss, K. J., Welton, E. J., Quinn, P. K., Johnson, J., Thompson, A. M., and Gordon, H. R.: Lidar measurements during Aerosols99. J. Geophys. Res., 106(D18), 20821-20831, 2001.

Wandinger, U. and Ansmann, A.: Experimental determination of the lidar overlap profile with Raman lidar, Appl. Opt., 41, 511514, 2002.

Wang, H.-C. and Walter, J.: Particle density correction for the Aerodynamic Particle Sizer, Aerosol Sci. and Tech., 6(2), 191-198, 1987.

Welton, E. J. and Campbell, J. R.: Micropulse Lidar Signals: Uncertainty Analysis. J. Atmos. Ocean. Tech., 19, 2089-2094, 2002.

Welton, E. J., Voss, K. J., Quinn, P. K., Flatau, P. J., Markowicz, K., Campbell, J. R., Spinhirne, J. D., Gordon, H. R., and Johnson, J. E.: Measurements of aerosol vertical profiles and optical properties during INDOEX 1999 using micropulse lidars, J. Geophys. Res., 107(D19), 8019, 18-1-18-20, 2002.

Willeke, K. and Baron, P. A.: Aerosol measurements principles, techniques and applications, Van Nostrand Reinhold, New York, USA, 143-195, 1993.

White, W. H., Macias, E. S., Nininger, R. C., and Schorran, D.: Size-resolved measurements of light scattering by ambient particles in the Southwestern U.S.A., Atmos. Environ., 28, 909-921, 1994.

WMO/GAW Aerosol Measurement Procedures Guidelines and Recommendations, (WMO TD No. 1178) - GAW Report No. 153, World Meteorological Organization, Geneva, 2003. 
Zender, C. S., Miller, R., and Tegen, I.: Quantifying mineral dust mass budgets: Terminology, constraints, and current estimates, Eos Trans. AGU, 85(48), 509-512, doi:10.1029/2004EO480002, 2004.

Zerefos, C. S., Kourtidis, K. A., Melas, D., Balis, D., Zanis, P., Katsaros, L., Mantis, H. T., Repapis, C., Isaksen, I., Sundet, J., Herman, J., Bhartia, P. K., and Calpini, B.: Photochemical activity and solar ultraviolet radiation modulation factors (PAUR): An overview of the project, J. Geophys. Res., 107(D18), 8134, doi:10.1029/2000JD000134, 2002. 